\title{
Maritime Aspects of Medieval Siraf, Iran: a pilot project for the investigation of coastal and underwater archaeological remains
}

\author{
Sorna Khakzad \\ East Carolina University (USA) and University of Leuven (Belgium), 1203 South Wright Rd., Greenville 27858, \\ USA, khakzads11@students.ecu.edu
}

\begin{abstract}
Athena Trakadas
Maritime Archaeology Programme, Department of History, University of Southern Denmark, Niels Bohrs Vej 9 , 6700 Esbjerg,Denmark,trakadas@sdu.dk
\end{abstract}

\section{Matthew Harpster}

Department of Classics, Ancient History and Archaeology, University of Birmingham, m.harpster@bham.ac.uk

\author{
Nicole Wittig \\ Tetra Tech, 175 Reds Road, Monroeton, PA 18832,USA, underwaterwittig@gmail.com
}

Siraf is well-known archaeologically and historically as an ancient port in the Persian Gulf that prospered during the medieval period. Siraf played a leading role in facilitating maritime and terrestrial trade, connecting long-distance Indian Ocean and China routes with those in the Gulf region. Despite its history, no previous research has been dedicated to the maritime infrastructure of Siraf. Through the '2012 Siraf pilot project' a preliminary survey of the underwater and shoreline remains of this ancient port city was conducted. The site's location is unique in many respects to trade routes and logistical considerations; however, its maritime infrastructure is difficult to assess in light of the extensive threats to the site.

Key words: Siraf, maritime history, ancient port, underwater heritage.

$\mathrm{T}$ he archaeological site of Siraf is located in southern Iran, roughly half-way along the north shore of the Persian Gulf. The site lies on the shore of a shallow bay partially occupied today by the fishing village of Bandar-e-Taheri or Tahīrī. The remains of Siraf stretch along a narrow coastal strip about $0.5-1 \mathrm{~km}$ wide backed by high foothill ridges of the Zagros Mountains which run parallel to the coast (Fig. 1). During the 9 th and 10 th centuries AD, Siraf reached its greatest extent of 250 hectares, spreading some $4 \mathrm{~km}$ along the shoreline, between the seasonal Rudkhanes (rivers) Kunarak and Kuchek, with a concentration of buildings towards the western side of the bay (Whitehouse, 2009: 17-19). In the past few decades, Tahīrī has expanded west over the remains; new coastal developments include a modern port with breakwaters, a corniche and parks along the shoreline, and an offshore fuelling terminal.

\section{Historical significance}

The earliest settlement of the site of Siraf is not entirely clear, but current evidence points to an initial occupation in the Sasanian period (AD 224-651). It has been suggested that a coastal fort was established here under Shapur II in the 4th century AD, along with other posts at Mahruban, Najiram, Rev Ardashir (Rishahr), Guzeran (Kujaran Ardeshir) and Hurmuzea on the east coast of the Gulf (Ricks, 1970: 342; Whitehouse and Williamson, 1973; Daryaee, 2003: 5-9). To date, the most coherent excavated Sasanian structure has been interpreted as a fort, dating to the 6th century, 


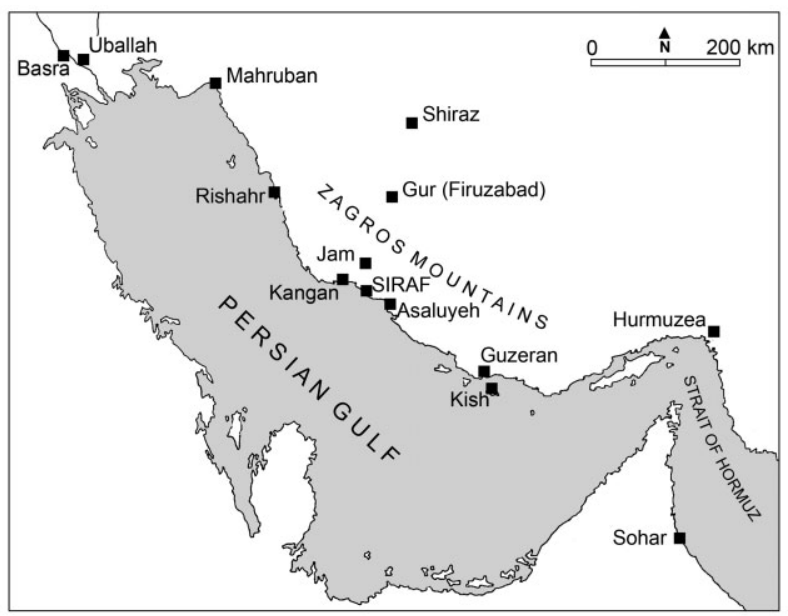

Figure 1. Map of the Persian Gulf, with sites mentioned in the text. (Drawing: A. Trakadas)

although there are earlier remains under this, also identified as Sasanian. Sasanian material, but no other structures, has been found at six other locations in Siraf. The presence of the fort is thought to have been tied to the caravan route to the inland site of Gur (Firuzabad), then a principal Sasanian city founded by the dynasty's first ruler, Ardashir (Whitehouse, 1974: 5-9; Whitehouse, 2009: 8). Imported objects, such as Red Polished Ware were also present, indicating that trade relations already had developed between Siraf (likely called Suriyanj during this period) (Tavakol, 1958: 545; Piacentini, 1992: 111-89) and the Arabian Sea region as far as the Makran and Sind coasts near the Karachi and Gujarat regions (Ricks, 1970: 342-43; Whitehouse and Williamson, 1973: 38-44; Whitehouse, 2009: 8, 100-1). Contacts extended west to at least Aden and south along the Indian coast and to Sri Lanka by the 6th century, and it is speculated that Persian merchants - though not necessarily from Siraf-travelled further east (Whitehouse, 2009: 99-100).

The evidence for the medieval period at Siraf is, in contrast to the Sasanian period, well represented both archaeologically and textually. The construction of the large Congregational Mosque, built over the Sasanian fort, was dedicated in AD 803-804 and completed in 825 (Whitehouse, 1980: 1). It appears that the fort was no longer in use just prior to this construction, although 7th- and 8th-century coins and ceramics suggest other parts of the settlement were occupied at this time. Importantly, Chinese ceramics first appear shortly before $c$.AD 750-775 (Hodges and Whitehouse, 1983: 147; Whitehouse, 2009: 12; Pashazanous et al., 2014). Textual references to the city over the following centuries, after the introduction of Islam to the region, focus on its commercial aspects and wealth first under Abbasid and later under Buyid dynastic control. The earliest reference to 'Siraf' occurs in the mid 9th century, when Ibn Khurradādhbih, writing in AD 844
48, mentions that Jewish merchants from the city traded with both the Mediterranean and India (Ibn Khurradādhbih, 1967: 41). In AD 851, Sulayman the Merchant, as recounted by Abu Zayd al-Sirafi, tells that 'Chinese vessels' began calling directly at Siraf, while Sirafi merchants transshipped goods to southern Arabia and East Africa (Ferrand, 1922: 18-19, 39). However, it is not clear what is meant by 'Chinese vessels'. These could be ships from China, or ships that sailed directly from the Indian Ocean to China, or both (Khakzad and Trakadas, 2014: 108-10).

Medieval historians such as Tabari (9th-10th centuries) (Tabari, 1987: 37/48), al-Muqaddasi (10th century) (al-Muqaddasi 1906: 96), al-Balkhi (10th century) (Ibn al-Balkhi, 1962: 158), al-Istakhri (10th century) (al-Istakhri 1870: 127, 139), Ibn Hawqal (10th century) (Ibn Hawqal 1965: 284-88; Whitehouse, 2009: 13), al-Mas'udi (10th century) (Al-Mas'udi, 1962: 94) and Yāqūt (12th-13th centuries) (Yāqūt 1955-57), describe Siraf and its importance as a trade port. These writers describe the wealth of the city's merchants, their well-appointed homes, and the public buildings. In addition they describe numerous goods, such as gems, ivory, exotic woods, spices and perfumes, traded from the Red Sea to the East African coast and Mozambique, India and the Far East, and porcelain and other ceramics from China. The city produced its own linens, pottery and possibly glass, and had a pearl market.

Goods sent overseas to Siraf reportedly arrived via large cargo ships or overland by caravan. Overland trade arrived through one of the few mountain passes which granted access from the region's interior and Shiraz, itself a thriving market under the Abbasids and Buyids that traded locally manufactured and imported wares (Le Strange, 1966: 257-60, 295-8). Siraf was also connected to other Gulf ports that interacted in local re-distribution networks, such as Basra and Uballah to the north and Sohar to the south. But its prosperity derived mainly from its role in long-distance 'Maritime Silk Road' trade that began in the mid 8th century (Agius, 2008: 75; Khakzad and Trakadas, 2014).

Remains of the medieval city of Siraf are extensive, representing the full expanse of the city during its period of greatest prosperity, in the 9th and 10th centuries. In addition to the Congregational Mosque, which was remodelled several times, there were smaller mosques, bazaars, merchants' houses, a fortification system, cisterns and aqueducts. Behind the low coastal foothills were cemeteries and beyond these valleys was an extensive network of roads and semi-arable land (Whitehouse 1968; 1969; 1970; 1971; 1972; 1974; 2009; Wilkinson, 1974: 123-32).

Al-Muqaddasi reports that an earthquake in AD 977 caused Sirafi merchants to transfer their bases south, to Sohar (al-Muqaddasi, 1906: 96; Banaji, 2007: 47-74). However, the archaeological evidence does not support the theory of an immediate collapse, and 
occupation clearly continued for a time. The breakdown of Buyid control in the mid 11th century gave rise to local khan rulers near the Strait of Hormuz, and concurrent shifts in alliances caused Sirafi merchants to settle elsewhere along the Gulf and in the Indian Ocean. In particular, Kish and Sohar began to control the Indian Ocean trade, and Siraf gradually declined, although the Congregational Mosque was kept in repair and cemeteries were used in the 12th century (Aubin, 1959: 2, 295-301; Whitehouse and Williamson, 1973; Agius, 2008: 79). When Yāqūt visited Siraf in the early 13th century, there were only a few residents left (Yāqūt, 1955-57: 295), and a small population was still present in the later medieval period, when the area was called Shilou (Whitehouse, 2009: 15-16).

\section{Previous Siraf research}

The prosperity of medieval Siraf was no longer visible in the 19th century, when G. B. Kempthorne, the first modern European to describe the site (Kempthorne, 1835), encountered poor inhabitants, scanty flora and 'a miserable town, redolent of odours. . .squalling children and yelping curs' (Kempthorne, 1857: 126; Wilson, 1928: 94). Kempthorne visited the site in 1835 when the post boat he was operating between the cities of Bassadore and Bushehr was caught in a storm and he had to anchor off Tahīrī (Kempthorne, 1857: 125). As a souvenir he took a carved ossuary back to his boat, and donated it to the Bombay Branch of the Royal Asiatic Society's museum in 1837, publishing a short narrative of his expedition to Siraf the same year (Kempthorne, 1837: 294-5; 1857: 128).

Kempthorne's account and, as made evident by his salvage, the potential of extant remains, were not the only reasons that his visit is important to modern scholarship. Prior to his investigation, the role of Siraf in early medieval Indian Ocean trade networks had been recognized but its location was not certain. In the 14th century, Ibn Battuta, for example, confused the city with the island of Kish (or Qais) far to the south, establishing an unfortunate precedent (Gibb, 1986: 407-8). Jean Baptiste Bourguignon d'Anville's 1751 map misplaced Siraf opposite the island of Qais/Kish (D'Anville, 1751) as did William Vincent in his 1797 analysis of Nearchus' voyage through the Gulf with Alexander's fleet (Vincent, 1797: 285; 352; 357-8; 360; 362-3). William Ouseley's 1819 essay of his journey through Persia did the same, as did James Buckingham who 'sought and enquired in vain' for the ancient city near Qais/Kish. James Morier apparently saw ruins near Tahīrī but did not equate them with Siraf (Morier, 1812: 51; 1818: 31-5; Ouseley, 1819: 174; Buckingham, 1829: 442-3).

Kempthorne's important identification was incorporated into successive discussions of Persian Gulf trade by Edward Rehatsek (1882) and Arnold Wilson (1927), forming the basis of Arthur Stiffe's 1895 pub- lication of his survey of Siraf and Tahīrī conducted 40 years earlier (Stiffe, 1895: 167). Notably, Stiffe's work contains a drawing of tombs in the nearby hills and possibly the earliest plan of the ancient site (Stiffe, 1895: 169-70). These early works, however, were eclipsed by Aurel Stein's detailed report. Although Stein's work at Siraf was a small part of a much larger expedition through India and Persia, it provided scholars with descriptions, drawings, photographs and plans demonstrating how the remains correlated with the ancient narratives (Stein, 1937: Plan 17, figs. 67-74, 76-7, Plate XXVII). The geographic setting of Siraf, for example, matched medieval descriptions (Stein, 1937: 202). Similarly, the pottery sherds he collected included examples from China, reinforcing connections previously suspected (Stein, 1937: 211-2).

Alastair Lamb briefly visited Siraf in 1962, to demonstrate the ancient city's connections with emporia in China, the Malay Peninsula and Indonesia (Lamb, 1964: 1-9). However, it was the series of seven survey and excavation seasons between 1966 and 1973 led by David Whitehouse, under the auspices of the British Institute of Persian Studies, which represent the most significant work at Siraf before the 1979 Iranian Revolution (Whitehouse, 1968; 1969; 1970; 1971; 1972; 1974; 2009). Whitehouse and his team studied the region along the coastline and into the adjacent hills, uncovering, labelling and documenting remnants of a pre-Islamic fort, domestic housing, a large mosque and other religious structures, bazaars, cemeteries, a hammam, and a potters' quarter with workshops and approximately 30 kilns (Whitehouse, 2009: 2, 5-8). The site's chronology was determined, divided into a preurban phase, an urban phase from the 9th to the 11th centuries $\mathrm{AD}$, and a non-urban occupation in the 15th and 16 th centuries. This was later refined to encompass six phases extending into the modern era (Whitehouse, 2009: 2, 9). Although Whitehouse's fieldwork ended in 1973, an Iranian expedition to the site conducted a brief field season in 1975 (Whitehouse, 2009: 8). Since then, little work has occurred at the site, although an international conference addressing both Siraf's history and its present state visited in 2005 (Aldsworth, 2005). Since 2007, the Historical Port of Siraf is on the UNESCO World Heritage Tentative List as evidence 'for Iranians' mastership and genius in seafaring, international relations and interaction with other near and far cultures and civilizations' (UNESCO, nd).

\section{Goals of the present project}

Previous archaeological work at Siraf and textual accounts suggest that it occupied an important maritime role in the early medieval period as one of the main Persian Gulf ports for long-distance Indian Ocean trade that also had connections with local maritime and land routes in the region. However, despite this apparent importance, no previous study of Siraf has focused on its maritime infrastructure, or 
attempted to investigate the material remains that clearly lie under water at the site. Therefore, this project was developed to investigate the potential archaeological evidence related to the maritime history of this ancient port city, and thereby illuminate aspects of the region's maritime heritage.

The remains of Siraf mapped during the Whitehouse campaigns show that some structures then on the coast are now partially eroded or lie in the present surf zone. Since the excavations in 1973 conducted by Whitehouse, there has been no accurate assessment of the state of the remains in the face of erosion and modern development. During a preliminary visit to Siraf in 2011, it was clear that material was distributed offshore of the site. In addition, interviews with local residents revealed that material was commonly found offshore-sometimes several hundred metres from the present shoreline. One major goal of the 2012 investigation was to find these remains and to see if the medieval shoreline of the town could be determined.

\section{Methods}

The site of Siraf was first visited by one of the authors in April 2011, which established the basis and feasibility for the present project, conducted 17-26 July 2012. In the interim, archival research was carried out, consisting mainly of studying Stein's archaeological report (1937), interim reports from Whitehouse's surveys and excavations $(1968 ; 1969 ; 1970 ; 1971 ; 1972 ; 1974)$, and the geological and natural processes in the Persian Gulf.

Although the goals of the project were to identify archaeological remains related to the maritime infrastructure of Siraf, they evolved during the course of the fieldwork because it was noted that some remains were in imminent danger of being destroyed by natural processes or development. Therefore it was decided to document also those remains deemed most under threat, regardless of their original use. This paper briefly reports the results of observation of threatened terrestrial remains using the same site-codes ascribed by Whitehouse, and then focuses on the results of the survey conducted along the shoreline and under water.

\section{Terrestrial methodology}

The terrestrial survey focused on coastal remains, with additional limited investigation of archaeological material in the foothills north and west of Tahīrī. Objectives included locating archaeological features and assessing the current state of preservation. Structures were identified by comparing contemporary evidence with Whitehouse's final site plans (Fig. 2) (Whitehouse, 1972: p.66, fig. 2) and were recorded with photography, drawing and hand-held GPS units. The survey concentrated on site components directly on the beach, specifically fragmentary wall remains, and structures including Site C (Bazaar), Site B (Congregational Mosque), Site D (Potters' Quarter), and Site J. For these archaeological



Figure 2. Map of Siraf with the location of the archaeological remains, as surveyed during the Whitehouse campaigns 1966-1973. (Whitehouse, 1972: 66, fig. 2, courtesy of the British Institute of Persian Studies, London)

remains, recording consisted of measured and schematic sketches, scaled photographs, and triangulation in the absence of a total station. Recording was simplified to scaled photographs for remains further inland consisting of irrigation-system remains in the mountains west of Tahīrī and cemetery complexes north of the settlement.

Two seasonal rivers run through the ancient and modern settlements, the Rudkhane Kunarak and, to the east, the smaller Rudkhane Shilau (or Shilou). Both were surveyed to assess erosion of buildings along the river banks and to see if river flow could have transported building materials to the sea. The Kunarak passes through a gorge formed by the coastal foothills and further inland to the Doband Valley. The Rudkhane Shilau passes through a small gorge in the low foothills behind Tahīrī, and then turns east through the Shilau Valley. Methodology followed that of the terrestrial survey; observation started in the upper parts of the town and the river courses were followed down to the shoreline.

The terrestrial methodology created a rapid assessment of site preservation. Quantitative statements regarding preservation were achieved by comparing results from the above methodology with measurements reported in previous site plans. Further 
qualitative statements were gathered from on-site observation and oral histories from Tahīrī residents. Preservation efforts are complicated by not only shoreline erosion but also encroaching modern construction. A local museum houses scant remains from Whitehouse's excavations, with more artefacts held in storage. One active measure taken by local authorities, witnessed during the current project, included building a make-shift seawall in front of Site B (Congregational Mosque) in an effort to diminish further degradation of shoreline remains. Workmen created this wall by stacking readily available stone approximately $1 \mathrm{~m}$ high and wrapping this structure in wire fencing. Including these observations aided in informing the team's recommendations for future research and site preservation.

In addition, a brief study on the impact of possible sea-level rise has been conducted. However, due to the lack of historic data on this matter, the result is at present very hypothetical.

\section{Underwater methodology}

The main focus of the underwater investigations was to assess the location, extent, and type of Siraf's submerged archaeological material, and determine appropriate methods and equipment for detailed archaeological investigation and possible excavation in the future. The methodology took into consideration the availability of technical and safety equipment, facilities and services on this part of Iran's coast, as well as the marine environment and conditions - which consisted of almost no boat traffic or fishing activity, little to no current, and very good visibility (more than $20 \mathrm{~m}$ ). The underwater methodology was two-fold: remote sensing using a side-scan sonar deployed from a fishing boat offshore over a broad area of Tahīrī Bay; and a diving/snorkelling reconnaissance inshore in selected areas.

The goal of the two-day remote-sensing survey was to outline broadly the extent of remains presently exposed on the sea-bed, in order to identify which areas to investigate during the diving/snorkelling survey. A Humminbird 1198c SI Fishfinder was fixed by a temporary mount to a $5 \mathrm{~m}$-long fibre-glass fishing boat based in the local port of Tahīrī. This fish-finder sonar was used in conjunction with a hand-held Garmin GPS. A general survey area was delineated from just east of Site B to the mouth of Rudkhane Kunarak, near Site J (Fig. 3). This area was chosen due to several factors including the presence of archaeological material along the shoreline between these two sites, and local fishermen having indicated that no visible remains were usually exposed on the sea-bed east of Site B. These observations were confirmed by several sonar runs. Extensive sedimentation west of the port of Tahīrī and modern construction taking place on shore here appear to be contributing factors to this lacuna. Survey runs were conducted parallel to the beach, beginning deeper and further offshore $(c .350 \mathrm{~m})$ and

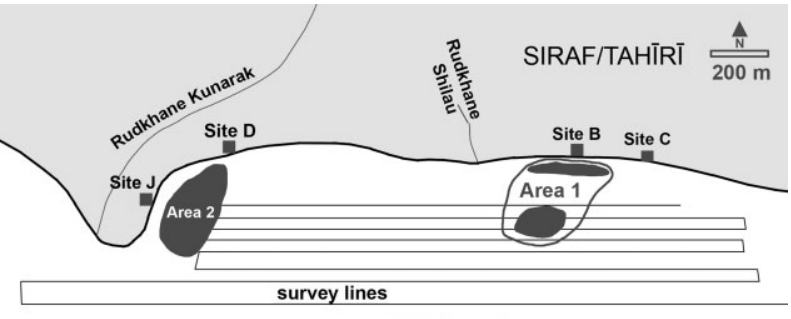

PERSIAN GULF

Figure 3. Areas surveyed offshore of Siraf in 2012. (Drawing: S. Khakzad and A. Trakadas)

then progressing inshore. Two smaller survey areas were then delineated as a result of the general survey: Area 1) just off Site B, with closer-spaced survey lines to determine the density of debris and their distribution in this specific area, and Area 2) offshore of the mouth of Rudkhane Kunarak. Several survey lines were run in the bay west of Tahīri to compare sea-bed geology.

The aim of the diving/snorkelling reconnaissance was to investigate material exposed on the sea-bed or located during the side-scan sonar survey-specifically, to characterize and to map the extent and type of visible debris, and to identify and record any in situ architectural features and artefacts. Dive tanks were rented from a commercial dive facility with a recompression chamber in Asaluyeh, $30 \mathrm{~km}$ south-east of Tahīrī. Shore-based diving/snorkelling was conducted over four days with a maximum depth limit of $7 \mathrm{~m}$. Divers visually surveyed the sea-bed and marked specific objects or agglomerations of objects with buoys, whose positions were recorded by a snorkeler on the surface with GPS. Snorkelling surveys were conducted in a similar manner in waters 1-3 m deep. Objects were recorded and scaled digital photographs taken. In addition, probing surveys were done in sand fields surrounding the areas of visible remains on the sea-bed.

\section{Results: shoreline survey}

\section{Site B, Congregational Mosque}

The most imposing building of Siraf is a large mosque situated along the beach, almost in the present centre of Tahīrī Bay (Fig. 4). The remains of this large building were first identified by Stein in 1931 (Stein, 1937: 205) as the possible Great or Congregational Mosque. In 1966 Whitehouse and his team conducted a rescue excavation on the site in their first season of work and confirmed the building as the Congregational Mosque described by Yāqūt (Yāqūt, 1955-57: 295; Whitehouse, 1980: 1, 23; Banaji, 2007). The mosque's foundation is dated by coins and an inscription to AD 803-804, being completed in 825. Periods of refurbishment followed, with final restoration in the 12th century (Whitehouse, 1980: 1-29; 2009: 15).

The mosque, at its largest extent, measured $55 \times$ $44 \mathrm{~m}$, and had several cisterns, an 'ablution area', a minaret and bazaar area immediately surrounding it 


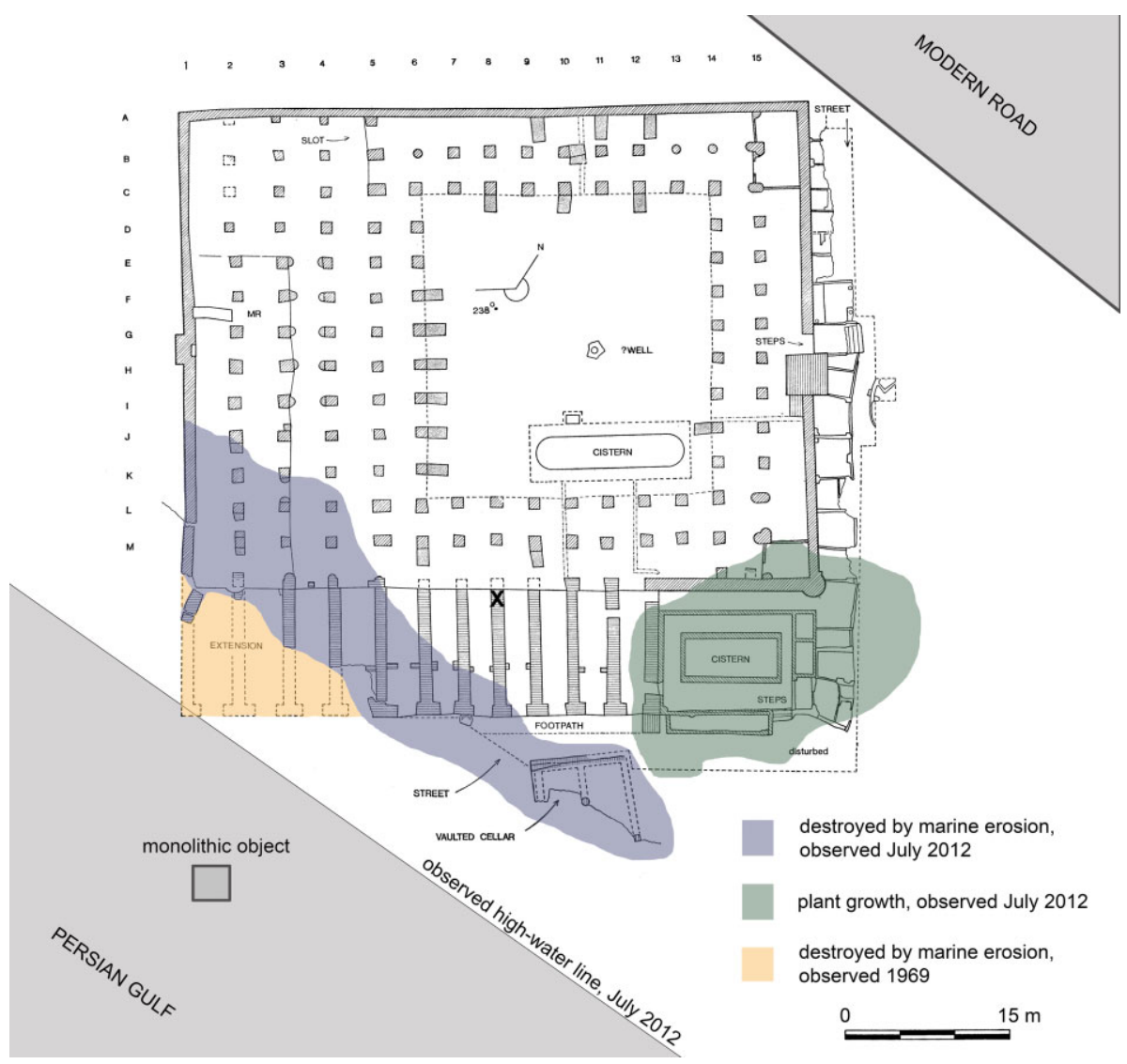

Figure 4. Whitehouse's proposed plan for the full extent of the Congregational Mosque (Site B), with erosion observed in 2012 indicated. (Drawing: Whitehouse, 1970: 3, fig. 1, courtesy of the British Institute of Persian Studies, London, with additions by S. Khakzad and A. Trakadas)

(Whitehouse, 1980: 1-29). Excavations by Whitehouse also revealed Sasanid occupation beneath the mosque to at least the 6th century, including what he identified as a 'fort', if not earlier (Whitehouse, 1968: 9-11; 1974: 5-9; 2009: 8).

Site B is now surrounded by development (houses and shops) to the east and west, and the road to the north has been widened and paved. On the southern side of the mosque, towards the sea, an 'ablution area' had been identified in 1973. A partial structure measuring $8 \times 9 \mathrm{~m}$, separate from the mosque, was also recorded and referred to as a 'vaulted cellar' (Whitehouse, 1969: fig. 2; 1980: fig. 2, pl. VIII; 2009: fig. 17). It is no longer visible. In addition, the southern-facing foundations of the mosque platform, which rest on the top of the beach, are being impacted. Measurements taken in 2012 reveal that c. $8 \mathrm{~m}$ of the length of these foundation walls have eroded away since 1973. Damage was also observed at the base of the remains of these walls, with deep cracks in some cases (Fig. 5). This damage is clearly due to wave action and general beach erosion.

\section{Site C, Bazaar}

Site C, part of what has been identified as the medieval bazaar that extended south from the Congregational

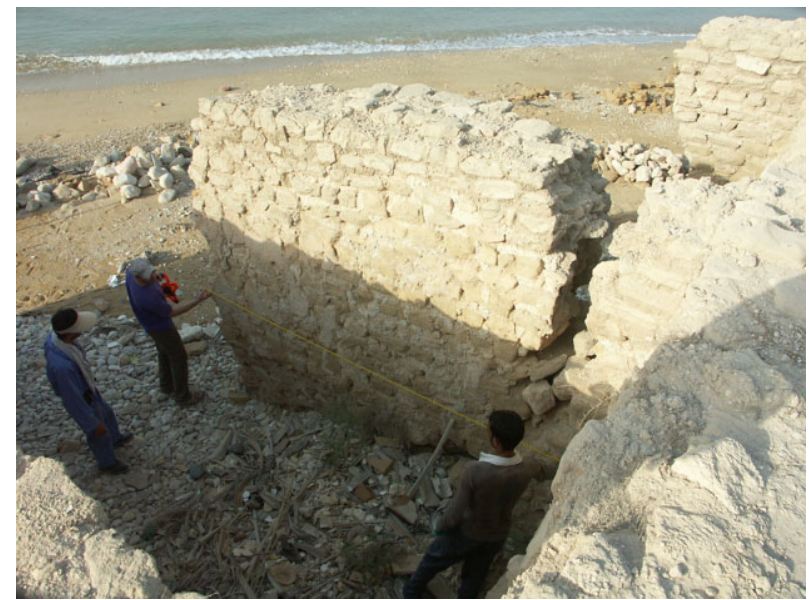

Figure 5. A seaward-facing buttress (marked with an ' $\mathrm{X}$ ' in Fig. 4) on the southern side of the Congregational Mosque (Site B) clearly showing the impact of erosion. (Photo: A. Trakadas)

Mosque, lies c. $125 \mathrm{~m}$ south of Site B (Fig. 6). The bazaar was used at various times from the early 9th century to after the 11th century (Whitehouse, 1968: 1, $4-5,11)$. Among the items found there were iron slag 


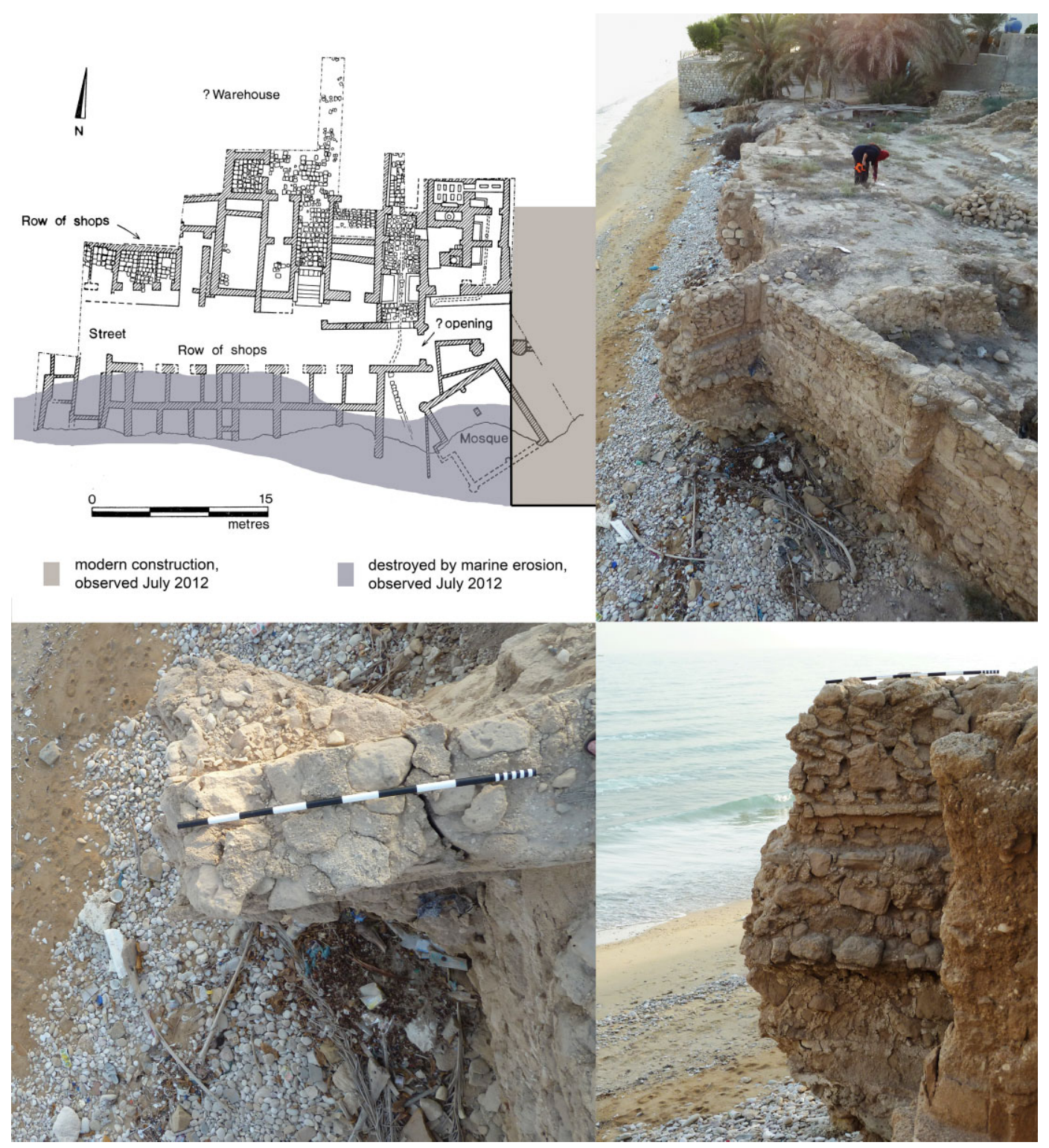

Figure 6. The Bazaar (Site C) in 2012, looking west and detail from side and above. Erosion since Whitehouse's survey is clearly visible. (Photos: M. Harpster and N. Wittig. Drawing: Whitehouse, 1971: 11, fig. 5, courtesy of the British Institute of Persian Studies, London, with additions by M. Harpster and A. Trakadas)

and clay tuyère, indicating a metal working area, green glass goblets, lusterware bowls from Syria or northern Persia, clay ovens, bronze needles and apothecaries' or jewellers' weights (Whitehouse, 1968: 19-21). A portion of road ran parallel to the shore bordered by shops with a possible warehouse and hammam to the north; more shops and a second mosque lay to the south. The excavations by Whitehouse suggested that the southern shops once extended to the west along the old shore as far as the Congregational Mosque (Whitehouse, 1971: 10; 2009: 29-33). Even in the first investigation of the site in 1966, Whitehouse noted the loss of portions of the shops and mosque south of the road, likely as a result of wave action. Assessments in
2012 affirmed Whitehouse's conclusion that wave action is destroying Site $\mathrm{C}$ structures. All but two of the north-south walls that once demarcated shop bays facing the sea are lost, as is most of the rear wall that separated them from the bays facing the street. Of the mosque, at the south eastern corner of the site, only the northern wall remains; the western wall, once containing the mihrab, is gone.

Environmental action represents the major threat to the site as modern development has been, with one exception, carefully limited to the edges of Whitehouse's excavated areas. Bordering the site to the north, where a medieval warehouse was suspected, is its modern equivalent containing tyres. To the west, a 


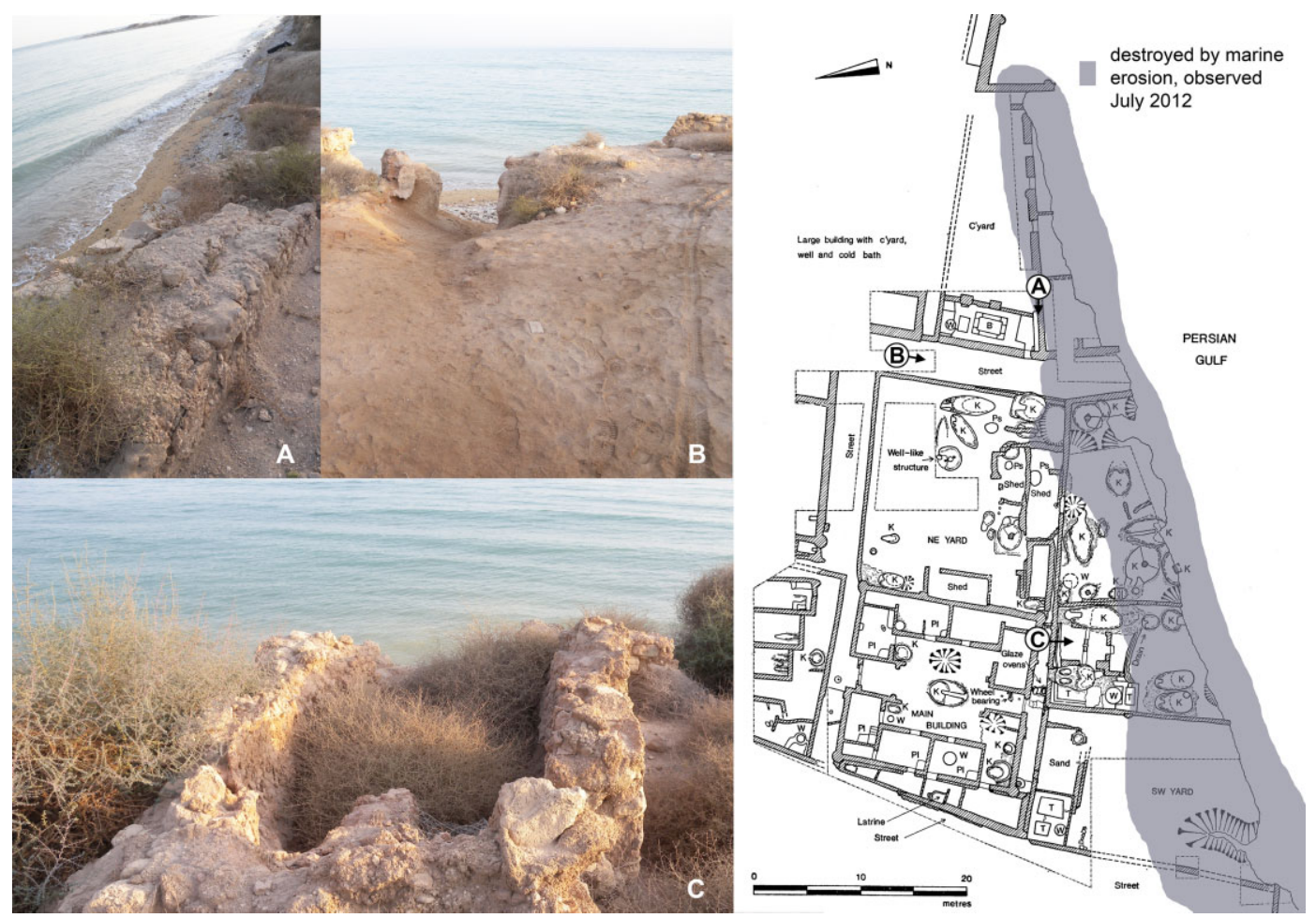

Figure 7. Whitehouse's plan of the Potters' Quarter (Site D) with observed erosion indicated; A) edge of one of the buildings along the shore; B) view down the 'street'; C) one of the rooms with kilns. Direction of photos indicated by arrows. General coordinates of Site D: N 2740.060; E 052 19.360. (Photos: S. Khakzad. Drawing: Whitehouse, 1972: 86, fig. 14, courtesy of the British Institute of Persian Studies, London, with additions by S. Khakzad and A. Trakadas)

modern house overlooking the sea has been built and a contiguous portion of Site $\mathrm{C}$ is used as a yard without any permanent structures. The greatest man-made damage is immediately east of the mosque, where an $8 \mathrm{~m}$-tall, square foundation has been built, presumably for a house. This foundation has buried part of the mosque, but does not interfere with any other exposed material.

It is likely, particularly in light of the carefully controlled development around this site and others, that Whitehouse's 1971 report and comprehensive plan of Site $\mathrm{C}$ has been used for modern zoning purposes, whereas his 1972 plan - which contained the newly exposed courtyard and wall to the east of the mosque-has not.

\section{Site D, Potters' Quarter}

Site D lies on top of a bluff 2-3 m high, directly above the beach on the western side of Tahīrī Bay, $400 \mathrm{~m}$ east of the mouth of Rudkhane Kunarak (Fig. 7). The area is estimated to have covered at least $45 \times 42 \mathrm{~m}$. Site D was identified as a Potters' Quarter because 30 kilns were located within five buildings dating primarily to the 10th century. Ceramics produced here included unglazed, fine 'eggshell' wares to large, red, coarseware jars, although some evidence of glazed ware and glass production is also suggested (Whitehouse, 1968: 12-14, 18-19; 1971: 12-15; 1972: 84; 2009: 7, 42-46).
The face of the bluff is clearly eroding, with layers of floors, walls, and sherds as well as slag heaps visible in its upper-most layers; it is unclear whether these latter are remnants of glass or glaze production. Erosion of the south-facing portions of Site D was noted by Whitehouse in 1966 (Whitehouse, 1968: 12); during the 2012 survey, it was apparent that further erosion had taken place.

Measurements were taken from features identifiable in Whitehouse's site plan to the edge of the present bluff, starting at the western side. The street at the eastern edge of the site is still recognizable and the small basin in the building on the east side of the street is still visible. However, the wall at the far eastern extent of the site is no longer present. Similarly to Site B, approximately $8 \mathrm{~m}$ of the walls present in 1973 at Site D that faced the beach have, in 2012, been lost to wave action.

\section{Site $J$}

Site $\mathrm{J}$ lies on the far western side of Siraf, just inside the western city wall, at the junction of the Rudkhane Kunarak and the beach (Fig. 8). This site, c. $100 \times$ $60 \mathrm{~m}$, has three separate structures associated with it: Buildings A, B and C. The site was first reported by Stein, who identified the main structure (Building A) as a fort, and noted that locally it is called 'Bang-i Sār', possibly misunderstanding 'Band as Bang', meaning 

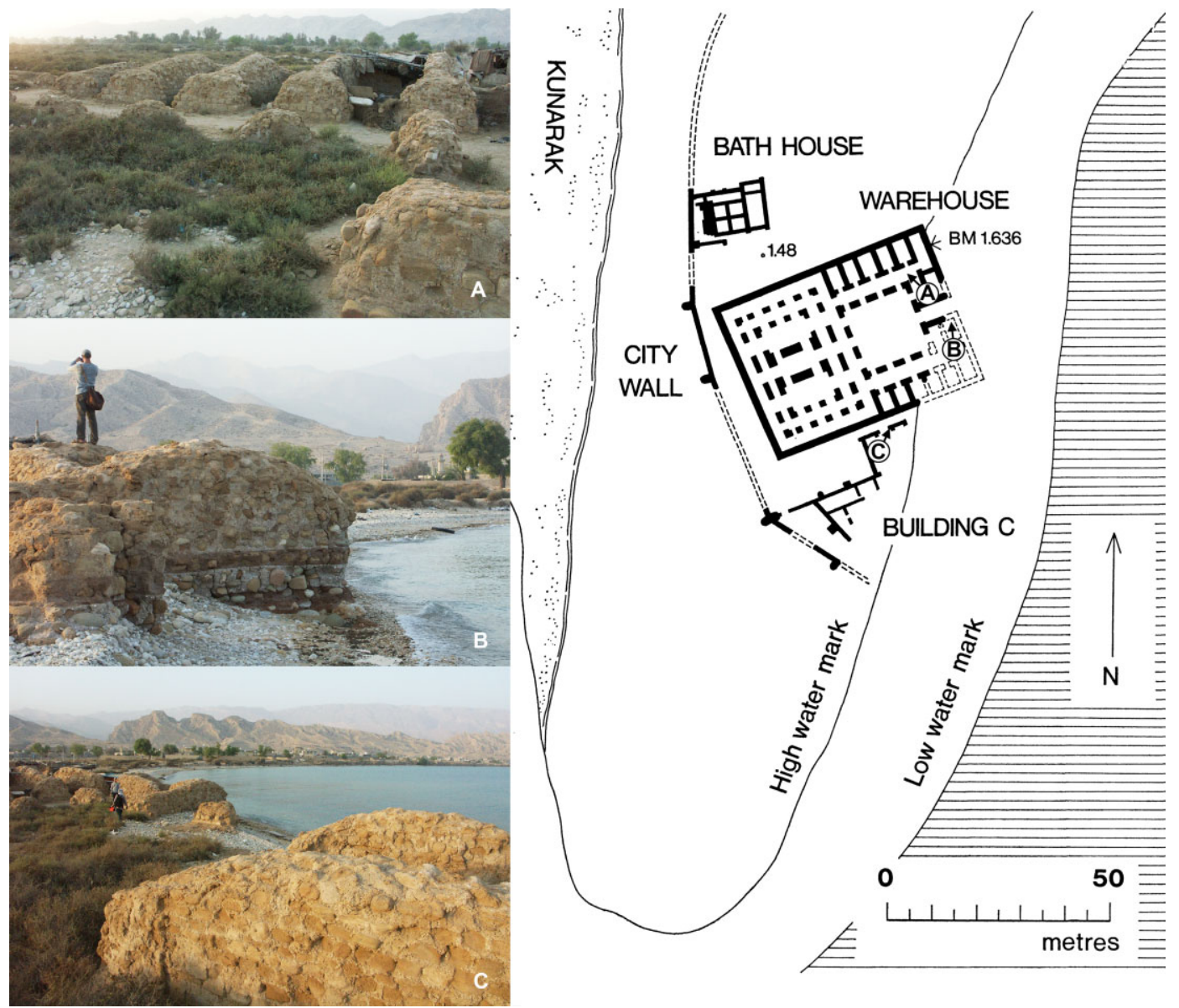

Figure 8. Whitehouse's plan of Site J; A) squatters' belongings at the entrance to Building A or 'warehouse'; B) detail of unworked stones and $s \bar{a} r \bar{u} j$ walls of Building A; C) looking north across the remains of Building A to the Zagros foothills and the valley of the Rudkhane Kunarak. Direction of photos indicated by arrows. General coordinates of Site J: N 27³9.93; E 052 19.176. (Photos: A. Trakadas, S. Khakzad and M. Harpster. Drawing: Whitehouse, 1974: 20, fig. 11, courtesy of the British Institute of Persian Studies, London)

'port/customs house' (Stein, 1937: 205; Whitehouse, 1972: 76). The functions of these buildings remain uncertain after excavation, but were referred to in excavation reports as a 'military complex', consisting of a 'caravanserai', 'warehouse', 'arsenal', 'hamman or bathhouse for troops' and a 'barracks' or 'building of unknown function'. Due to its position on the coast, it has been suggested that the latter might have had a lighthouse or light tower associated with it, although there is no architectural evidence for this. This building was likely erected at some point in the 10th century, and abandoned in the mid 11th century, but no firm construction date was established during excavations (Whitehouse, 1972: 74-78; 1974: 18-21; 2009: 21).

The remains of the 'bathhouse' and city wall were not immediately discernible, although traces of several metres of walls possibly belonging to these were visible flush with the dirt road leading to the beach. Some traces of the city wall mapped by Whitehouse were noted. The remains of the large 'warehouse' structure, however, are distinct and, as it is the closest to the beach of the three buildings of Site $\mathrm{J}$, it was documented in 2012. Presently, a fisherman's shed stands several metres north of this building, and squatters are living in some of the structure's rooms. It is a large structure, 51 $\times 38 \mathrm{~m}$, divided into two sections: the eastern section with a courtyard surrounded by small rooms, and the western section with two rows of surrounding piers that might have been the bases of structural columns. The building's long axis is oriented approximately northeast/south-west, with the entrance at the north-east end, at the present beach. The walls of unworked stones and $s \bar{a} r \bar{u} j$, a particularly water-resistant and recognizable mortar (Wulff, 1967: 113), are preserved to a height of $2.25 \mathrm{~m}$ (Whitehouse, 1972: 74-8; 2009: 21).

When documented in $1973 \mathrm{c.} .15 \mathrm{~m}$ of the southern side of the 'warehouse' and c. $25 \mathrm{~m}$ of its eastern side had been lost to beach erosion. In 2012, it was noted that a further $c .2 .5 \mathrm{~m}$ of the seaward-facing ends of the two walls flanking the building's east entrance had eroded away. Some cracks have appeared in the walls along the eastern face and a few pieces of wall have 
collapsed. Despite these observations, the 'warehouse' generally appears to be the most stable of those structures recorded in 2012. It occupies the lowest elevation of any structure investigated; its floor is at the crest of the low beach and a few centimetres of its foundations are covered at high tide.

\section{Shoreline remains between Sites $D$ and $B$}

Archaeological remains are exposed in the profile and on top of the c. $3 \mathrm{~m}$-high bluff that runs along the western length of the current Tahīrī Bay shore, extending continuously from Site D to Site B, for a distance of more than $1250 \mathrm{~m}$ (Fig. 9). These remains were surveyed in 2012 and compared to Stein and Lamb's descriptions of 1931 and 1964, respectively.

When Stein visited the site in 1931, he reported a 'quay wall' or 'sea wall' visible along the top of the beach, standing $15 \mathrm{ft}(5 \mathrm{~m})$ high with triangular and semi-circular buttresses. Stein noted that it ran 450 yards $(411.5 \mathrm{~m})$ east of, and in front of the Congregational Mosque (Site B) (Stein, 1937: 204-205). Stein's observations were based on exposed material at the time, and not excavation.

Similarly, Lamb wrote in 1964 that a 'sea wall' standing higher than $10 \mathrm{ft}(3.33 \mathrm{~m})$ stretched along the length of the shoreline (Lamb, 1964: 7). Lamb does not mention a specific location but rather vaguely refers to the sea wall separating the site from the Gulf and being set back from the water by $10 \mathrm{ft}(3.33 \mathrm{~m})$ of beach. Like Stein, Lamb's statements were based on visible remains exposed, not excavation.

Unlike Stein and Lamb, Whitehouse reports an absence of evidence for a sea wall, noting only scant wall remains near Site D in an area not surveyed by Stein. Whitehouse remarks on the prominence of the mosque's ruins with no surviving trace of the sea wall observed by Stein in the same area (Whitehouse, 1968: 5; 2009: 21).

During the 2012 survey, some wall segments were observed running along the top of the beach. However, they do not appear to be the ancient sea wall mentioned by Lamb or Stein. Preservation of the remains varies greatly, as a result of a combination of factors both natural and man-made. The remains are dry-laid or of stone and mortar construction, with only one building being observed to have $s \bar{a} \bar{u} j$ or waterresistant mortar. Facing the beach, some walls also have plastered surfaces including moulded decoration, traces of wooden ceiling beams, and parts of narrow partitions (walls) in addition to remains of stone flooring. These features together indicate interior spaces and attest that the structures presently exposed on the bluff are the eroded remains of rooms in buildings that once extended towards the beach.

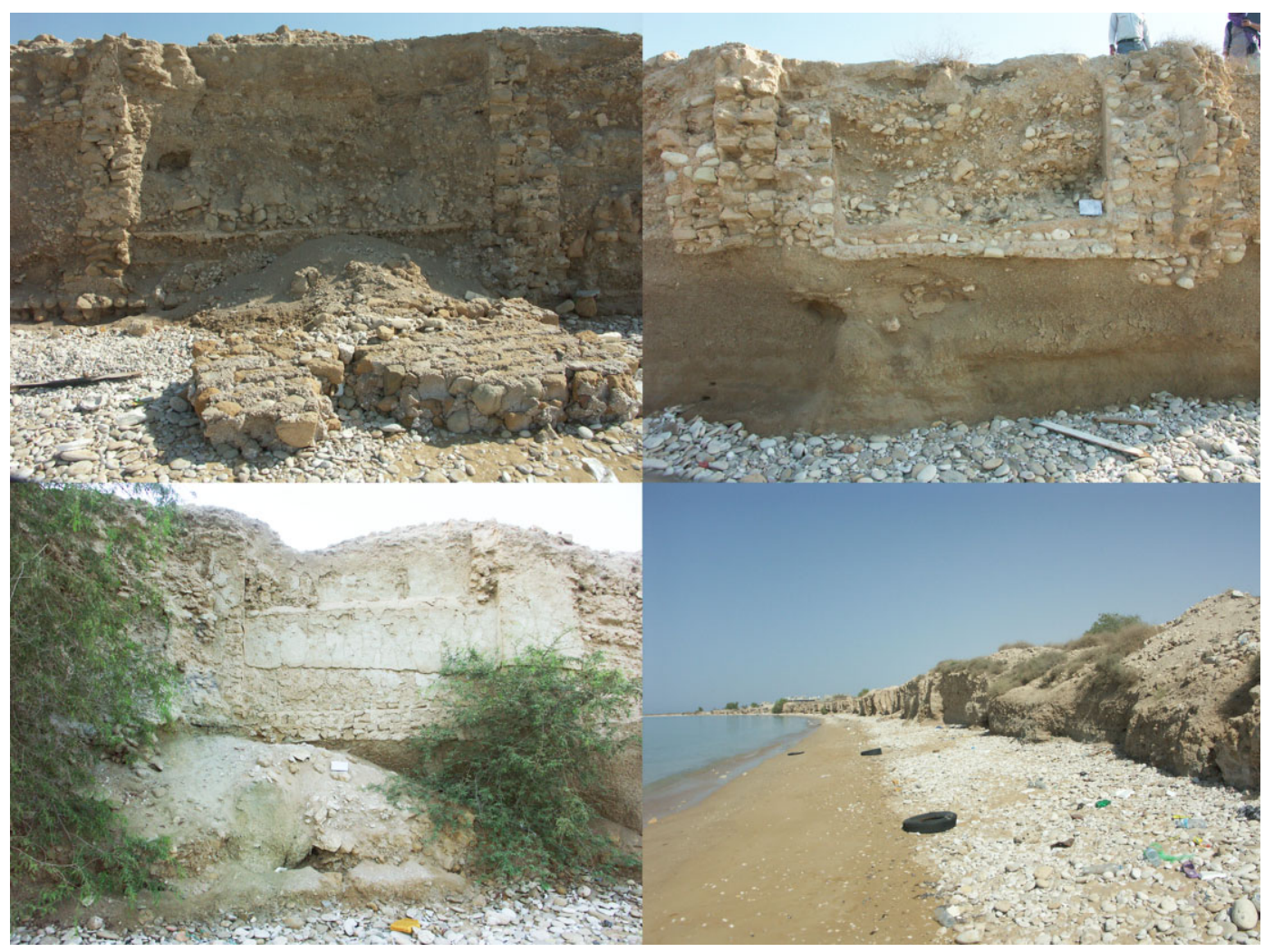

Figure 9. Remains along the beach between Site D and Site B, of dry-laid constructions, plastered surfaces including moulded decoration, traces of wooden ceiling beams, narrow partitions and stone flooring indicating interior spaces of buildings that once extended further towards the beach. (Photos: A. Trakadas) 


\section{Rivers}

The survey of the Rudkhane Kunarak and Rudkhane Shilau showed erosion and destruction of walls that lined the two rivers' courses. The remains of stone structures and buildings were extant along the course of the rivers. In some areas along the banks, protective walls or levees were observed that probably were erected to prevent damage to buildings from river floods. However, most of the stones in the river-beds and river mouths are worn smooth by water and it is not possible to determine if they were originally building materials from upper levels in the city.

\section{Results: underwater survey}

The underwater surveys offshore of Siraf in 2012 covered an area not previously investigated. Some of what was identified during the course of this survey was found to relate to material from the previous terrestrial archaeological excavations and surveys, and clarified, at least preliminarily, the possible character, extent, and type of debris present under water. Although the sea-bed of Tahīrī Bay appeared largely sandy, side-scan sonar survey revealed two major concentrations of material visible on the sea-bed: Area 1 directly in front of Site B, and Area 2 from the mouth of Rudkhane Kunarak (near Site J) to just east of Site $D$. These areas were investigated visually during the diving/snorkelling survey and were found to be comprised of small stones and rubble, covered by a small amount of marine growth.

Area 1 (Fig. 10) covers an area c. $250 \mathrm{~m}$ from east to west, and $c .300 \mathrm{~m}$ from north to south. Within this

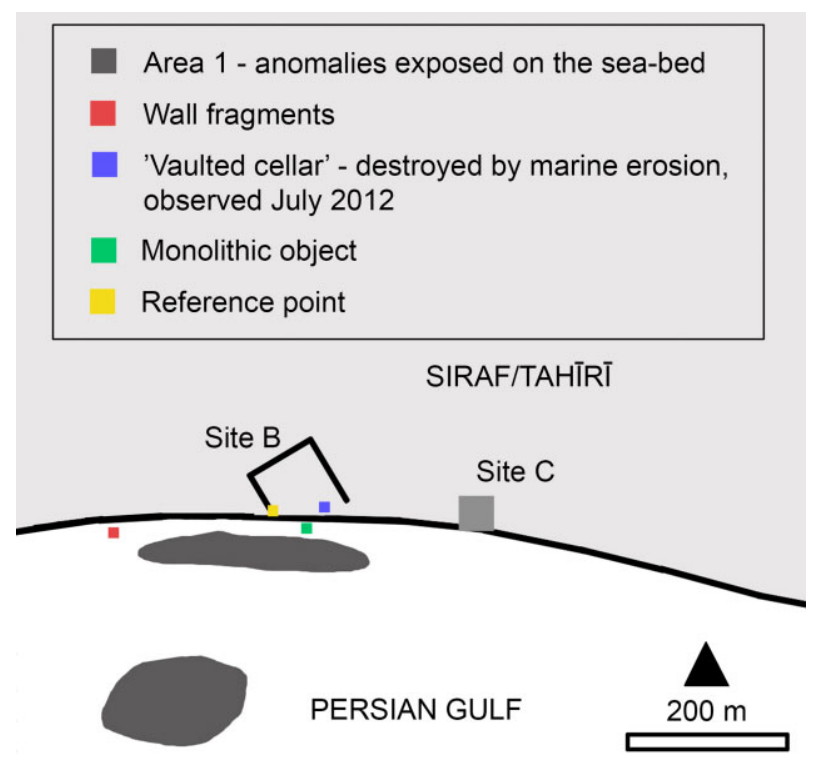

Figure 10. Underwater survey of Area 1, in front of Site B, the Congregational Mosque. The boundaries of the exposed remains were recorded using GPS. The reference point is: $\mathrm{N}$ $27^{\circ} 40^{\prime} 01.60^{\prime \prime}$; E $52^{\circ} 20^{\prime} 06.41^{\prime \prime}$. (Drawing: S. Khakzad and A. Trakadas) area two zones of stone and rubble are exposed on the sandy sea-bed. The first lies at a distance of c. $40-50 \mathrm{~m}$ from the reference point of the existing wall of the Congregational Mosque on the beach. The second, separated by a sand field, is situated at a distance of 180 to $350 \mathrm{~m}$ from the same reference point. Both areas have irregular shapes that are altered by sand movement and sedimentation.

Area 2 (Fig. 11) extends $c .550 \mathrm{~m}$ from the mouth of Rudkhane Kunarak north-east towards Site D. The zone of stone and rubble exposed on the sea-bed here is widest (c.95-100 m) near Site J, and follows the curvature of the shore until Site $\mathrm{D}$, with material exposed at a distance of $c .80 \mathrm{~m}$ from the current top of the beach.

The material visible under water consists of small stones and rubble of local sandstone and limestone, covered with soft flora that can easily be removed and cleaned off. Generally, the stones are irregular in shape, but some were approximately rectangular with two flat sides and a depth of $0.08-0.10 \mathrm{~m}$ (Fig. 12). There are also some blocks with more regular and rounded edges, forming a semi-circle, or ellipse. The overall distribution of material protrudes no higher than $1 \mathrm{~m}$ above the present sea-bed in front of Site B, and protrudes no higher than $0.20 \mathrm{~m}$ from Site $\mathrm{J}$ to Site $\mathrm{D}$. In front of Site B, the stone and rubble debris was fairly densely concentrated, consisting largely of stone/ rubble with little or no sand present, and only slightly less so in the area from Rudkhane Kunarak to the east of Site D. Here stone or rubble could be separated by $0.20-1 \mathrm{~m}$ of sand, with larger sand fields closer to Site D. It proved difficult to distinguish whether any exposed material included in situ architectural features. Two sections of coherent architectural features were observed $c .3 \mathrm{~m}$ apart in shallow water; both are $c .1 \times$ $1 \mathrm{~m}$ sections of stone and mortar (Fig. 13). These

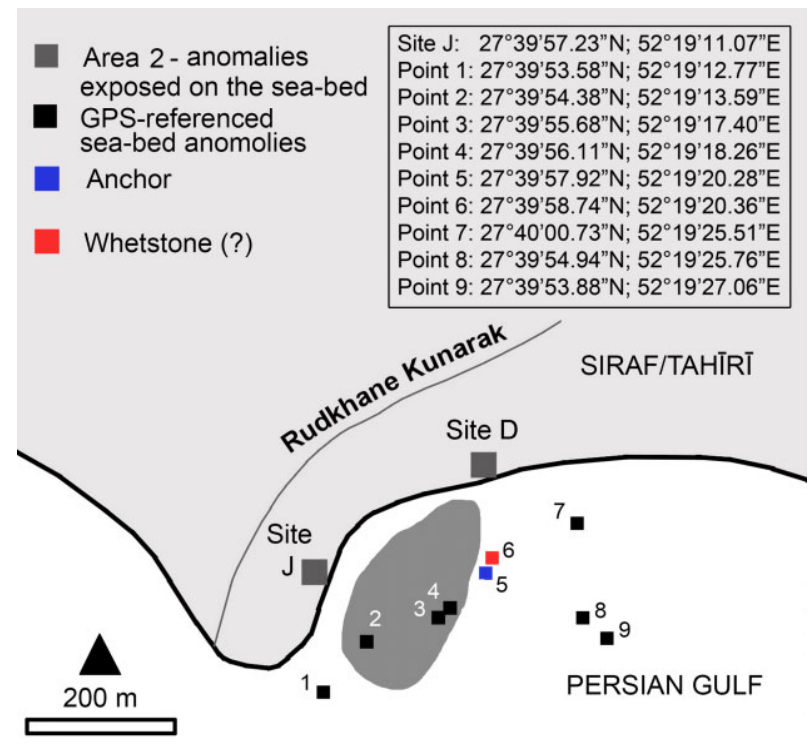

Figure 11. Underwater survey of Area 2. (Drawing: S. Khakzad and A. Trakadas) 

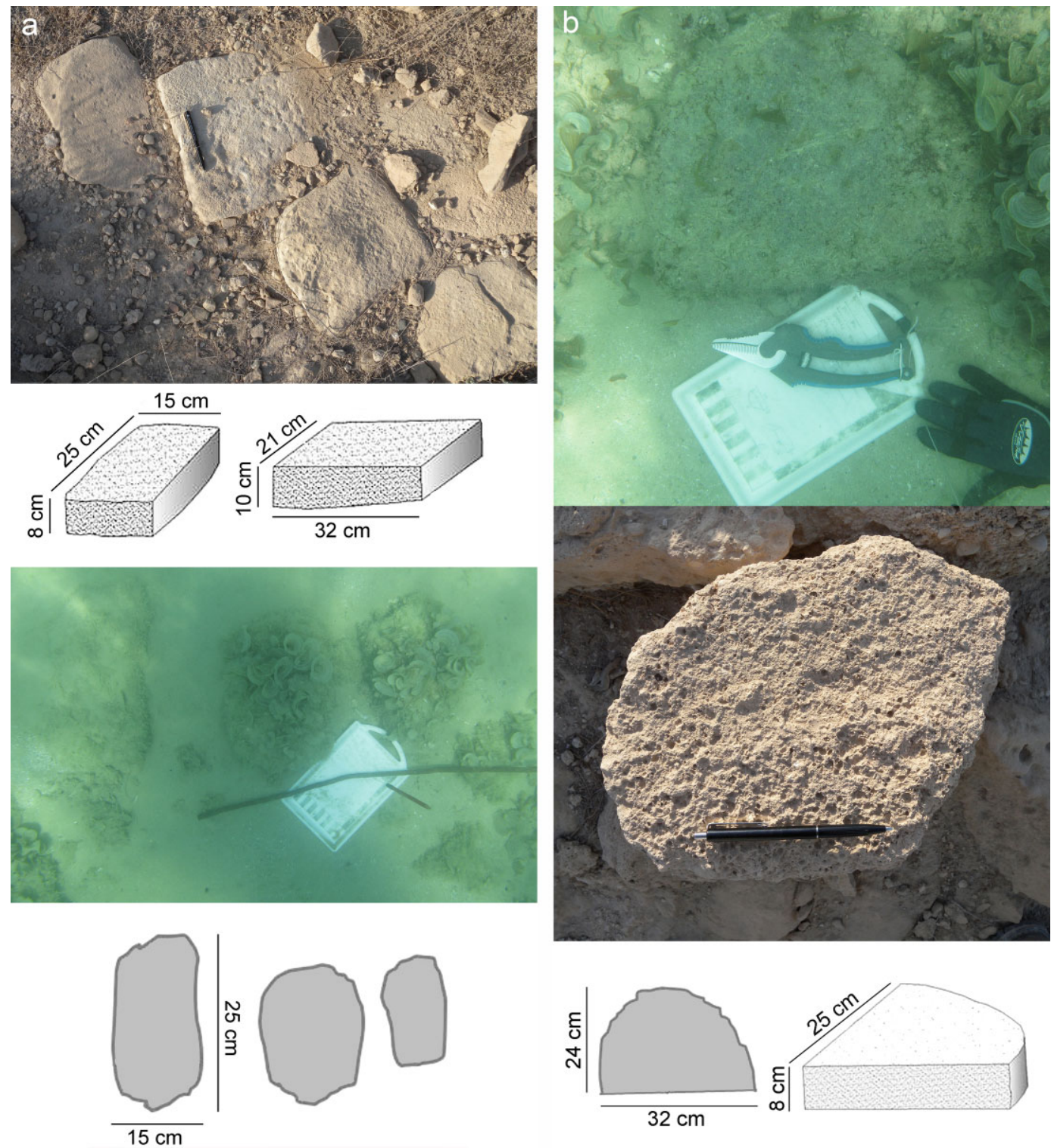

Figure 12. a) Examples of the materials observed and recorded on land and on the sea-bed. On land they serve as flooring and water-channel covers; $b$ ) Examples of materials with semi-circular or semi-oval shapes found on land and under water. The largest observed under water is $c .25 \mathrm{~cm}$ long and $c .8-10 \mathrm{~cm}$ high. (Photos and drawings: S. Khakzad)

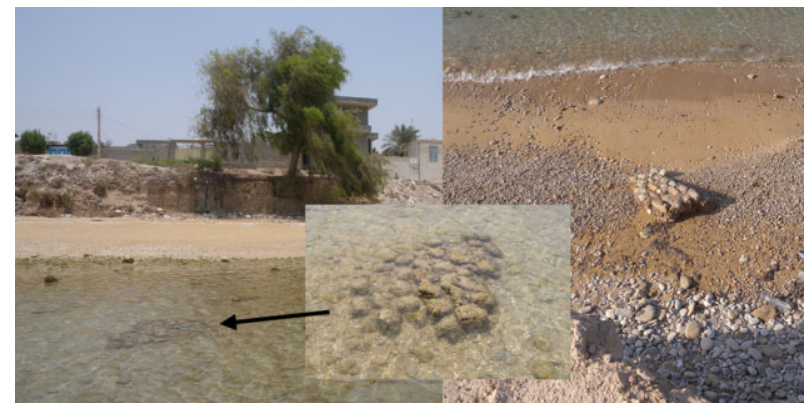

Figure 13. Fragments of a stone wall in the sea, similar in construction to collapsed pieces on shore. Coordinates: $\mathrm{N}$ 2740.011; E 052²0.005. (Photos: S. Khakzad) remains are clearly wall fragments but do not appear to be in their original location. The distance between these two fragments and the existing remains on shore is about $50 \mathrm{~m}$, but it is not clear from where they originated.

It was noted that stones located near the mouth of the Rudkhane Kunarak are very smooth and rounded compared to others seen during the underwater surveys and likely were deposited in the sea after having been in the river for some time. River pebbles were also noted outside of the area at the mouth of the river and, as can be seen today, may also have been used as a medieval construction material.

Probing surveys were conducted in the sand fields surrounding exposed material in front of Site B and 
from Rudkhane Kunarak to east of Site D. It was found that stone and rubble debris was present everywhere systematic probing was conducted. The only variable was the depth of the sand deposits over the material, which ranged between $0.20 \mathrm{~m}$ and $0.70 \mathrm{~m}$. There was no one particular area probed where the sand layer was consistently thicker or thinner.

In the survey areas, several artefacts were identified and recorded. Near Site J, one large black oval-shaped stone was observed with a groove along part of its centre, measuring $0.40 \times 0.30 \times 0.10 \mathrm{~m}$ (Fig. 14). Stones with similar grooves have been identified at Chogha Bonut and Chogha Mish in Khuzestan, in southern Iran (Alizadeh, 1996: 80); it is possibly a whetstone.

In front of Site B, a rectangular-shaped stone object, $1.11 \times 1.30 \mathrm{~m}$, was located in the tidal zone $c .34 .5 \mathrm{~m}$ from the northern (sea-side facing) end of the seventh buttress from the east end of the Congregational Mosque (Fig. 15). It is a nearly square monolithic object with edges a few centimetres thick and high along three sides, with a fourth open side. It is at least

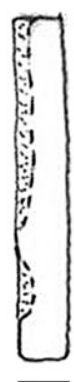

$\overline{10 \mathrm{~cm}}$
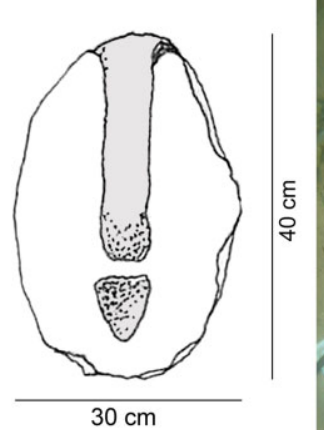

Figure 14. Dark-coloured, oval-shaped stone with a groove along part of its centre, possibly a whetstone. (Photo and drawing: S. Khakzad)
$0.40 \mathrm{~m}$ deep, but due to its location in the tidal zone, it was not possible to excavate it fully; it certainly extends deeper into the sand. The function of this object is unknown. However, there are similarly shaped objects, identified as watering troughs or cisterns, found in the Lir Valley, behind Tahīrī (Barzgar, 2008: 50). Such an object could be part of a water-distribution system. Simply due to its find location, this object may be associated with the building identified by Whitehouse as a 'vaulted cellar' (now gone) in the 'ablution area' (Whitehouse, 1969: fig. 2; 1970: fig. 6; 1980: pl. VIII(b); 2009: fig. 17), on the south side of the mosque, but this association is tentative.

Two stone anchors were found under water (Fig. 16). One, buried and badly eroded by saltwater and bio-fouling, has an exposed diameter of $c .0 .20 \mathrm{~m}$ (no depth measurement possible). The other, in better condition, is pear-shaped, $0.50 \mathrm{~m}$ long and $0.37 \mathrm{~m}$ maximum width, with a circular hole of $80 \mathrm{~mm}$ diameter in the upper middle area. A third anchor was found broken on land in the debris next to a new house on the beach $(0.56 \mathrm{~m}$ maximum preserved length, maximum thickness $0.17 \mathrm{~m}$ ).

Other anchors have been previously identified at Siraf: two fragmentary stone shanks of grapnel or IndoArabian type anchors were found in House R and House $\mathrm{E}$ at Site F. Whitehouse dates these to the mid 11th century by their find locations. A complete example in local sandstone, $0.77 \mathrm{~m}$ long, was found between Site B and Site C in a modern house (Whitehouse, 1970: 14-15, pl. XIIf). These anchors, widely distributed in the Indian Ocean, have long, nearly rectangular stone shanks, with holes at each end for wooden flukes and cable (Vosmer et al., 2005: 131-7).

Although not previously identified at Siraf, singlehole stone anchors are not unusual in this region, and have an extended period of use. For example,

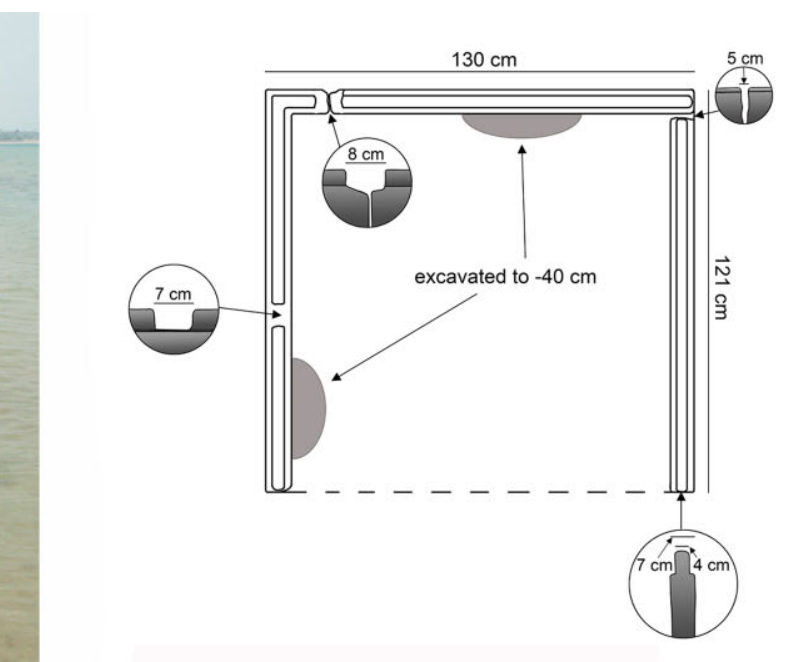

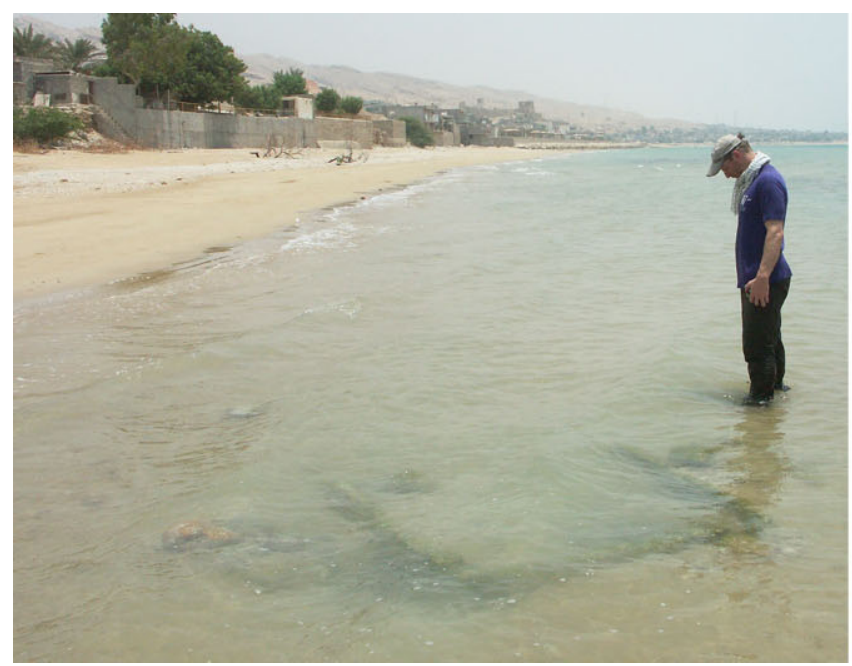

Figure 15. A rectangular-shaped monolithic stone object found in the sea in front of Site B (view looking east from find site). It lies c.34.5 metres from the middle buttress of the Congregational Mosque (marked with an ' $\mathrm{X}$ ' in Fig. 4). Coordinates: N 2740.010; E 052²0.107. (Photo: A. Trakadas; Drawing: S. Khakzad, A. Trakadas, N. Wittig and M. Harpster) 

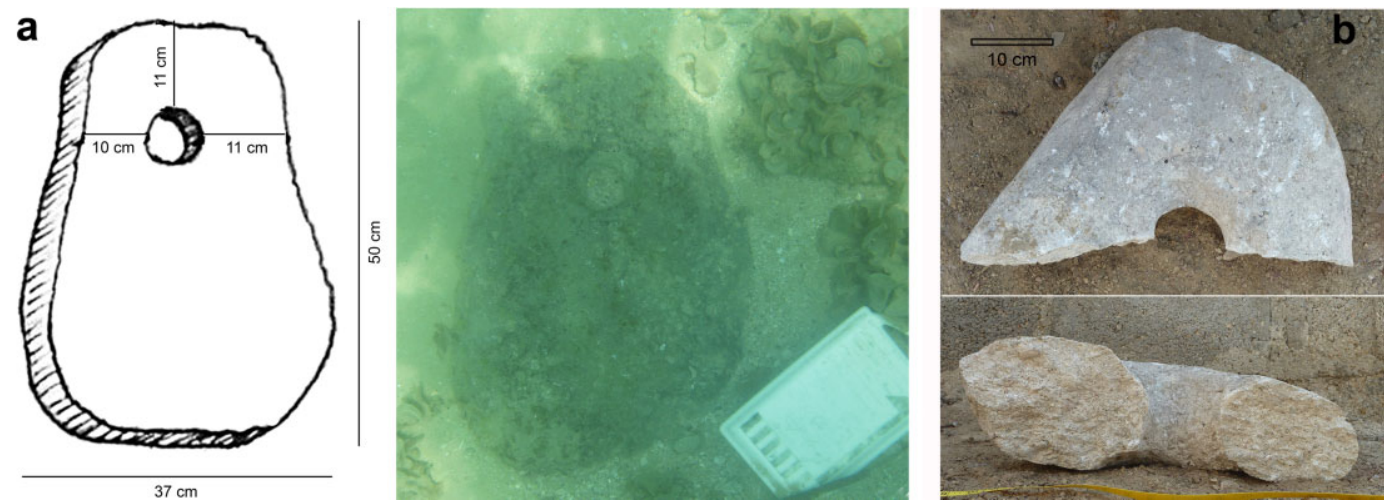

Figure 16. a) One of the stone anchors observed during the underwater survey. Coordinates: N 2739.950; E 052 20.084 , (Photo and drawing: S. Khakzad); b) a broken stone anchor observed on land between Sites B and D, on the 3 m-high bluff behind the dry-stone wall. (Photos: M. Harpster)

single-hole stone anchors dated to $2000 \mathrm{BC}$ have been found at Qalat-al-Bahrain, at the gate to the Northern Rampart (now on display at the Qalat-al-Bahrain Museum, Bahrain). Single-holed ringstone-type anchors are also known from Qalhat, Oman, the Maldives, and the western coast of India (Vosmer, 1999: 248-63). It is possible that the single-hole stone anchors located under water at Siraf were reused as building stone in structures that have now eroded into the sea; they are made of the same local sandstone used for building. Therefore, although they are indications of Siraf's maritime past, their presence in the debris layer may not be directly linked to distinct anchorages.

\section{Summary of results}

From the preliminary survey conducted in July 2012 some concrete conclusions can be made; however, many more questions emerged from our observations. In general, anthropogenic processes, such as development on land and offshore, new buildings, and road construction are having a destructive impact on the archaeological remains of Siraf at a fairly rapid rate. Remote sensing under water has confirmed Whitehouse's assertion that Siraf did not extend west of Rudkhane Kunarak, and has delimited an area with visible remains - although this may vary with conditions affecting sand deposits. The high level of erosion, up to $8 \mathrm{~m}$ in the past 30 years, seen along the bay has deposited a vast debris layer in the sea. Much of the material recorded is likely to have been produced by this process. The so-called 'sea wall' described in earlier accounts could not be located and neither could any buildings with a particularly maritime character, although one building in this area had waterproof mortar. It has been firmly established that the current coastline does not represent that of medieval Siraf. The buildings currently standing on the bluff and eroding into the sea do not have the characteristics of sea defences. The position of the Congregational Mosque, currently on the sea edge, and the accounts of local fishermen of material at some $300 \mathrm{~m}$ from the beach, hint that a substantial part of the built town may have eroded into the sea prior to Whitehouse's excavations. The rivers have eroded some material from their banks, and river-worn material was identified in the sea at the mouth of Rudkhane Kunarak. However, it is not thought that the river itself is responsible for the extensive debris layer recorded under water.

No distinct structures could be discerned under water but further work is required to ascertain if this is the result of structures having been covered with the debris layer or the shifting sands encountered in the bay. Since the walls of Siraf's medieval building consist of worked and unworked stone, and the remains under water are not cohesive, the disarticulated stone and pebbles visible on the sea-bed are difficult to assign to specific built structures. In the course of this study, the impact of sea-level rise in this area was also investigated. The available data are limited to the period 1990-2009, where the average relative sea-level change is at a rate of $+1.96(+0.21) \mathrm{mm} / \mathrm{yr}$ within the western Persian Gulf. Corrected for vertical land movement, the average sea-level change is calculated at a rate of $+2.27 \mathrm{~mm} / \mathrm{yr}$ (Ayhan and Alothman, 2009). One hypothesis is that the structures of Siraf that were closer to the sea could have, in addition to the passage of time and/or earthquakes, been affected by the result of sea-level rise. The preliminary results of the 2012 survey suggest that the mortar of these structures could have been washed away by waves and currents while the stone blocks remained in place; over time, the oncecohesive stone walls, such as those visible along the shoreline on land, fell apart. Thus the debris layer could represent the combination of construction material eroded from the shoreline by wind and wave action and the slow degradation of in situ structures inundated by rising sea-levels.

Some evidence of Siraf's maritime past is seen in the presence of stone anchors and ship graffiti. A graffito of a ship with two or three masts was discovered during the 1970-71 excavation season at Site K, a large 

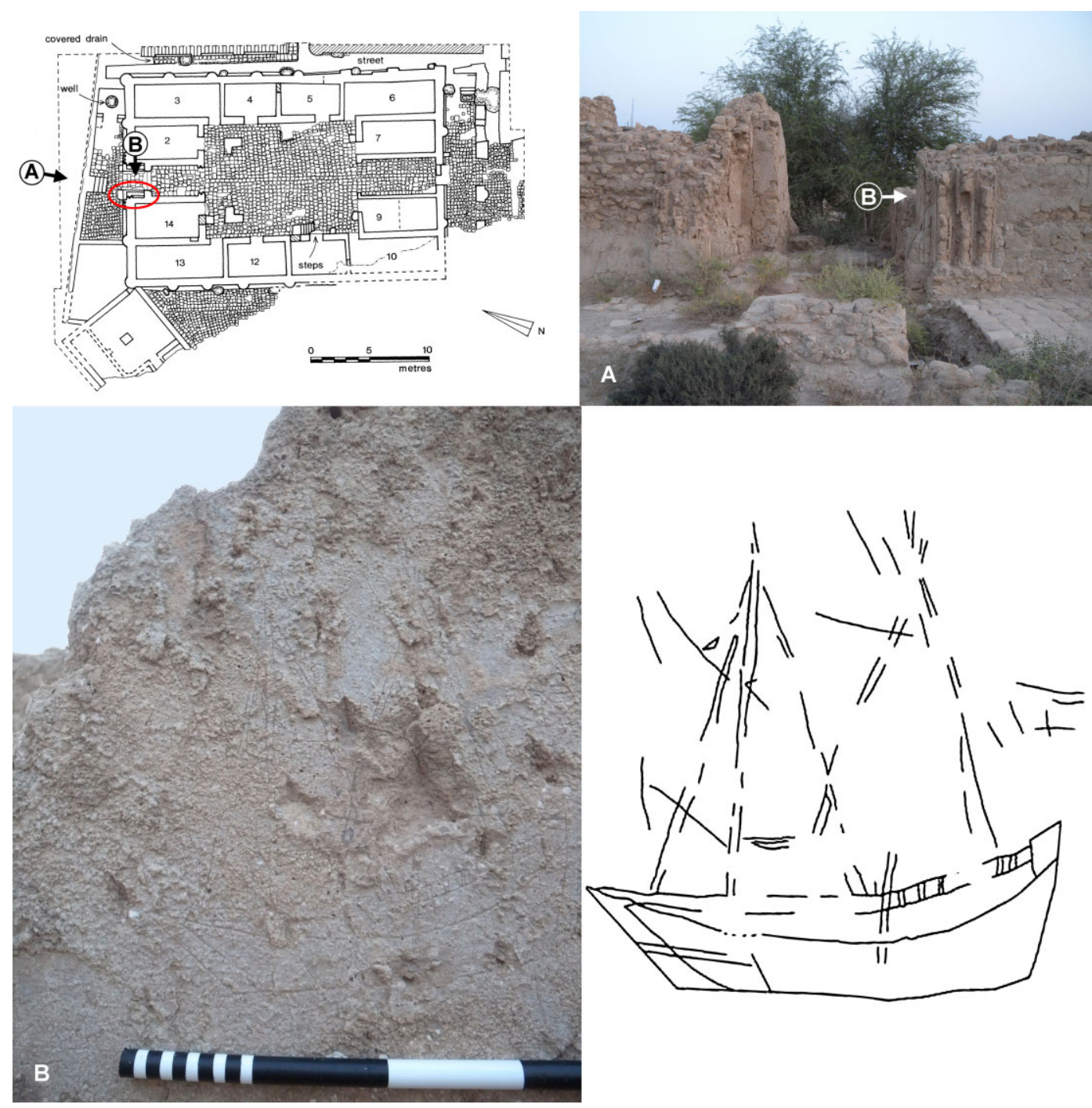

Figure 17. The largest of the boat graffiti on the entrance wall of House W, Site F (10th or 11th century). Direction of photos indicated by arrows. (Drawing: S. Khakzad, Photos: M. Harpster and S. Khakzad. House plan Whitehouse, 1969: 49, fig. 2, courtesy of the British Institute of Persian Studies, London)

palatial complex above and to the east of the city centre (Whitehouse, 1972: 74, fig. 8, 75). During the present survey in July 2012, a small cluster of boat graffiti, previously unknown, was located at the entrance of a house at Site F, along the course of the Rudkhane Shilau (House W, a 10th- or 11th-century merchant's residence; for site, see Whitehouse, 1974: Whitehouse, 1969: 49, fig. 4; see Fig. 2 for location). On the western side wall, a well-preserved and several smaller lesserpreserved boat graffiti were observed (Fig. 17). The largest ship graffito is $343 \mathrm{~mm}$ long and $362 \mathrm{~mm}$ high; a second, smaller graffito located above the large one is $146 \mathrm{~mm}$ long. There are a few less well-preserved graffiti to the right of the first two.

During the underwater survey, no ceramic sherds were observed on the sea-bed, although there are large quantities on the beach (particularly at the pottery kilns at Site $\mathbf{J}$ and in the exposed shoreline bluffs between Site $\mathbf{J}$ and Site D). A reason for the lack of visible sherds on the sea-bed during the preliminary underwater surveys could be the consistency and movement of the sand combined with wave action, which might have buried the sherds. (See for example, discussion of a similar phenomenon in the harbour at Caesarea Maritima: Hohlfelder, 2000; Reinhardt et al., 2006). Further investigation, including test excavations, will assist in formulating the nature of the site processes under water in the bay.

\section{Discussion}

The significance of Siraf in medieval maritime trade routes, and the number of vessels mentioned in contemporary texts as 'Sirafi', has led many scholars to suggest that the port city was also a major shipbuilding centre with dockyards (contemporary sources 
mentioned above, Yajima, 1977: 195-208; Freeman-Grenville, 1981; Hsieh, 2004: 81; Agius, 2008: 142; Sherrif, 2010: 157). No contemporary sources reference shipbuilding specifically at Siraf, but during Whitehouse's excavations at the Site P1 (Fig. 2), at the mouth of Rudkhane Shilau, vats in the ground, an encrusted black substance and a whale bone were found. Whitehouse suggests that this area, within which structures date to the 10th century, could have been used to heat whale blubber for caulking ships, suggesting that 'the beach in the vicinity of Site P1 was used by shipwrights' (Whitehouse, 1974: 18; 2009: 51).

The specific location of Siraf does not seem ideally suited for a port, at least from a topographical perspective. The site at present is not adjacent to a natural deep embayment with protective headlands. The area for anchorage offshore lies exposed to prevailing southern winds and currents (Kämpf and Sadrinasab, 2006). Moreover, considering that coastal erosion has occurred at the site, it is very possible that Siraf proper during the medieval period extended further south, maybe even to the points where material was reported exposed on the sea-bed some $300 \mathrm{~m}$ in front of Site B, the Congregational Mosque. This would suggest that even less of an embayment existed previously. In addition, annual precipitation is low along this portion of the Iranian coast, averaging $30 \mathrm{~mm}$ a year, and an extensive system of cisterns - 49 inside the city walls, 75 estimated extra-muros (Whitehouse, 2009: 23; Wilkinson 2009) - aqueducts, dams, and wells had to supply this key resource. Wood was used extensively in the construction of wealthy merchants' homes and mosques, and would have been required for shipbuilding or ship repairs too, but had to be imported from India and the East African coast (al-Muqaddasi, 1906; Ibn al-Balkhi, 1962: 158; Whitehouse, 2009: 9-14). The deficiency of these natural resources was noted by contemporary sources (al-Istakhri, 1870: 127; Wilson, 1928: 94; Ibn Hawqal 1965: 284-88), as was Siraf's heat, humidity, and generally poor port location, mentioned specifically by al-Baladuri (Murgotten, 1924: 134-5).

The placement of Siraf instead seems to have been based on its landward orientation: it is the closest coastal site to the pass that leads inland through the Zagros foothills to the agricultural city of Jam, and Firuzabad, the Sasanian capital, and then later to Shiraz, the capital under the Abbasid and Buyid Dynasties (see Fig. 1). The small ridge behind the coastal strip adds a level of protection to the city, and helps explain why the city walls have only been identified at the east and west sides of the site. According to Stein, some remains of the city fortifications were still visible along the coast in the 1930s, but due to the high levels of erosion, nothing can be seen today (Stein, 1937: 202-12). The Rhudkhane Kunarak and Kuchek, although seasonal, would add another level of defence, with the river-beds serving as moats or protective ditches.

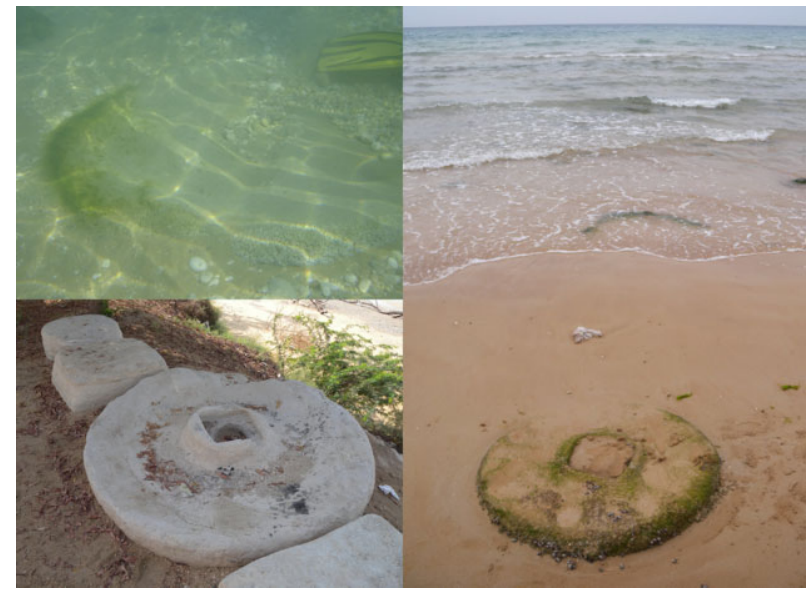

Figure 18. Mill stones, present on land in Siraf, were also found in the tidal zone. Image bottom-left coordinates: $\mathrm{N}$ 2740.015; E 052 20.079. (Photos: S. Khakzad and N. Wittig)

Siraf's provisioning was largely dependent on the maritime network of which it was part, although the logistics of how this operated are at present speculative (Khakzad and Trakadas, 2014). Although long stone quays or jetties dating to the first several centuries $\mathrm{AD}$ are present at Rishahr, modern Busheir, $245 \mathrm{~km}$ north of Tahīrī (Whitehouse and Williamson, 1973: 40, 42, Pl. IIB; Whitehouse, 2009: 21), no such structures have yet been identified at Siraf. It is likely that ships anchored offshore, as is the current custom and that of historical periods. Mooring or anchoring in the bay is currently possible when the weather is calm, and transport between ship and shore is carried out by lighters (Ma'soomi, 2005: 41-3; Nezami and Beladi, 2005). Several millstones were located during the 2012 survey in the tidal zone these could have been re-purposed for mooring stones at some period (Fig. 18).

Medieval sources also mention that the anchorage at the port of Siraf was ideal for the large Indian Ocean trading ships seeking to avoid the dangers of sudden storms in the Persian Gulf and the hazardous delta and whirlpools of Basra and Uballah, at the head of the Persian Gulf (Sauvaget, 1948; Mu Genlai et al., 1983: 7; Chaudhuri, 1985). Siraf is located half-way along the northern shore of the Gulf, and was an ideal transit point where large vessels could off-load their goods to smaller vessels that transited between the Gulf ports (Chaudhuri, 1985: 47-9; Hourani, 1995: 69-74).

If maritime infrastructure ever existed at Siraf, erosion by waves and sediment transport, as well as bio-fouling have played a strong role in destroying or possibly camouflaging the archaeological remains. The rate of sand and sediment movement is significant in this area, especially due to industrial and oil-extraction activities east and west of Siraf, at Kangan and Asaluyeh, and sea-bed exploitation has been noted to affect sediment movement (Jankowski and Zielke, 2001: 3487-521). In addition, considering the dominance of eolian transport of dust in this area, sediment 
deposition varies in different seasons (Clemens, 1998). Therefore, the number of anomalies visible in different seasons on the sea-bed varies.

\section{Future goals}

The archaeological remains of Siraf are under imminent threat due to changing conditions along the coast and growth of the modern village, although their research potential is still great. Discrepancies between extant structures and published plans and commentaries were noted in 2012, and some remains need re-identification. In addition, future terrestrial survey should provide further archaeological assessment and inform potential management planning. It is highly recommended that a complete survey of shoreline features be conducted, both to establish a record of the extant evidence and for reinterpretation of exposed structural remains. For future study, laser scanning documentation of all known graffiti, a photomosaic of coastal remains, and a total station survey of the entire site are recommended. An updated site plan would be beneficial for understanding spatial relationships of archaeological remains and for comparative purposes with previous studies, especially in light of coastal erosion. In addition, although current observations when compared with historical accounts have allowed some preliminary statements to be made concerning the nature of archaeological material exposed along the beach, a full comparative architectural analysis would add insight into the various construction methods and materials observed, and structures' original functions.

In light of the findings from the 2012 underwater survey, a sub-bottom profiler survey would assist in determining the extent of the offshore buried remains. Cleaning the exposed stone material under water may help distinguish more objects such as anchors, grindstones and other possible maritime objects, or parts of built structures. In addition to the probing that was conducted during the 2012 project, further survey using a sub-bottom profiler and test excavations must be conducted in order to understand the distribution and nature of remains in the sea.

Future work at the medieval port of Siraf should inform our understanding of ports and their physical infrastructure in the Sasanian, Abbasid and Buyid periods. Through further investigation, the importance of the town's maritime aspects may be brought to light. Further fieldwork should focus on creating a hierarchy of preservation problems to prepare better management planning of the archaeological and cultural remains, which would in turn support Siraf's registration on the UNESCO World Heritage Site List.

\section{Acknowledgements}

We thank the Iranian Centre for Archaeological Research and its representatives for the survey permit, and Susan Cheraghchi for facilitating the post-project seminar at the Iran National Museum. Logistical support was provided by the Bushehr Office of Cultural Heritage and Tourism, East Carolina University and Dr Larry Babits, Mr Sarvari of the Asaluyeh Commercial Dive Club, and Mohammad Kangani of the Siraf-Pars Institute NGO. Soheila Dejam Shahabi, Ahmad-Reza Khakzad, and Cyrus Behpour generously provided financial support for the project.

\section{References}

Agius, D. A., 2008, Classic ships of Islam from Mesopotamia to the Indian Ocean. Leiden.

Aldsworth, F., 2005, History of archaeological surveys in Siraf port, in Proceedings of the International Congress of Siraf Port, November 14-16, 2005, Bushehr-Iran, 8-27. Bushehr Branch of Iranology Foundation \& Bushehr University of Medical Sciences: Bushehr.

Al-Istakhri, 1870, M. J. de Goeje (trans. \& ed.), Kitab Al-Masalik wa-al-Mamalik. Leiden.

Alizadeh, A., 1996, Excavations at the prehistoric mound of Chogha Bonut. Khuzestan 80, Iran.

Al-Mas'udi, 1962, C. Pellat (trans. \& ed.), Les Prairies d'or. Paris, Paris, Societe Asiatique, Collection d'ouvrages Orientaux.

Al-Muqaddasi, 1906, M. J. de Goeje (trans. \& ed.), Ahsan al-Taqasim fi Ma'rifat al-Aqalim. Bibliotheca Georaphorum Arabicorum, Leiden.

Aubin, J., 1959, La Ruine de Siraf et les Routes du Golfe Persique aux XIe et XIIe siècles. Cahiers de Civilisation Medievale 2, 295-301.

Ayhan, M. E. and Alothman, A., 2009, Sea level rise within the west of Arabian Gulf using tide gauge and continuous GPS measurements. Geophysical Research Abstracts, 11, EGU2009-6006-1.

Banaji, J., 2007, Islam, the Mediterranean and the Rise of Capitalism. Historical Materialism 15, 47-74.

Barzgar, A., 2008, Siraf: Dreams' port. Bushehr.

Buckingham, J., 1829, Travels in Assyria, Media and Persia. London.

Chaudhuri, K. N., 1985, Trade and Civilization in the Indian Ocean. An economic history from the Rise of Islam to 1750. Cambridge.

Clemens, S. C., 1998, Dust response to seasonal atmospheric forcing: proxy evaluation and calibration. Paleoceanography 13.5, 471-90.

D’Anville, J-B. B., 1751, Premiere Partie de la Carte d'Asie contenant La Turquie, L'Arabie, La Perse, L'Inde en deca du Gange et de la Tartarie ce qui est limitrophe de la Perse et de l'Inde. http://www.geographicus.com/P/AntiqueMap/ ArabiaPersiaIndia-anville-1751\#sthash.N16F6jVW.dpuf (accessed 23/10/2014)

Daryaee, T., 2003, The Persian Gulf trade in late antiquity. Journal of World History 14, 1-16. 
Ferrand, G. (trans.), 1922, Voyage du marchand arabe Sulaymān en Inde et en Chine. Rédigé en 851, suivi de remarques par Abū Zayd Hasan (c.916). Paris.

Freeman-Grenville, G. S. P. (trans.), 1981, Buzurg Ibn Shahriyar al-Ramhormuzi, The Book of the Wonders of India: Mainland, Sea and Islands. London.

Gibb, H. A. R., (trans.), 1986 (1st edn 1958), The Travels of Ibn Battuta, AD 1325-1354, Vol. I. New York.

Hodges, R. and Whitehouse, D. 1983, Muhammad, Charlemagne and the Origins of Europe: archaeology and the Pirenne thesis. London.

Hohlfelder, R. L. 2000, Anastasius I, mud, and foraminifera: conflicting views of Caesarea Maritima's harbor in Late Antiquity, Bulletin of the American Schools of Oriental Research 317, 41-62.

Hourani, G. F., 1995 (2nd edn), Arab seafaring in the Indian Ocean in ancient and early medieval times. Princeton, NJ.

Hsieh, M. L., 2004, The Navigational Route of the Belitung Wreck and Late Tang Ceramic Trade, in M. L. Hsieh (ed.) The Belitung Wreck: Sunken Treasures from Tang China, 2004, 76-91. New Zealand.

Ibn al-Balkhi, 1962, G. Le Strange and R. A. Nicholson (trans. \& eds), Farsnameh. Gibb Memorial Series, N.S. I, London.

Ibn Hawqal, 1965, J. H. Kramers (trans. \& ed.), Kitab Surat al-Ard. Bibliotheca Georaphorum Arabicorum, Leiden.

Ibn Khurradādhbih, 1967 (2nd ed.), M. J. de Geoje (trans. \& ed.), Al-Masalik wa-al-Mamalik. Bibliotheca Georaphorum Arabicorum, Leiden.

Jankowski, J. A. and Zielke, W., 2001, The mesoscale sediment transport due to technical activities in the deep sea. Deep Sea Research Part II: Tropical Studies in Oceanography 48.17, 3487-521.

Kämpf, J. and Sadrinasab, M., 2006, The circulation of the Persian Gulf: a numerical study. Ocean Science 2, $27-41$.

Kempthorne, G. B., 1835, Notes Made on a Survey along the Eastern Shores of the Persian gulf in 1828. Journal of the Royal Geographical Society of London 5, 263-85.

Kempthorne, G. B., 1837, On the ruins at Tahrie. Transactions of the Bombay Geographical Society 1, 294-95.

Kempthorne, G. B., 1857, A Narrative of a Visit to the Ruins of Tahrie, the supposed site of the ancient City of Siraff, also an Account of the ancient Commerce of the Gulf of Persia etc. The Transactions of the Bombay Geographical Society XIII, 125-39.

Khakzad, S. and Trakadas, A. 2014, The world in a grain of sand: Siraf, in S. Sindbæk and A. Trakadas (eds), The World in the Viking Age, 108-110. Roskilde.

Lamb, A., 1964. A visit to Siraf, an ancient port on the Persian Gulf. Journal of the Malaysian Branch of the Royal Asiatic Society 37, 1-19.

Le Strange, G., 1966, The lands of the eastern caliphate. London.

Ma'soomi, G., 2005, Siraf, Tahiri's Port. Tehran.

Morier, J., 1812, A Journey through Persia, Armenia, and Asia Minor to Constantinople in the Years 1808 and 1809 . London.

Morier, J., 1818, A Second Journey through Persia, Armenia, and Asia Minor, to Constantinople between the years 1810 and 1816. London.

Mu G. L, Wen J. and Huang Z. H. (eds \& trans), 1983, Zhongguo Yindu Jianwenzhi [Documents on China and India]. Beijing, Zhonghua Shuju.

Murgotten, F., 1924, (trans.) Al-Baladuri, Kitab Futūh al-Buldan, II, 134-5. New York.

Nezami, G. H. and Beladi, S. A. A., 2005, The historical port of Siraf. Siraf Pars Institute, Siraf.

Ouseley, W., 1819, Travels in Various Countries of the East; More Particularly Persia, Vol. I. London.

Pashazanous, H. R., Montazer Zohouri, M. and Ahmadi, T., 2014, Sea trade between Iran and China in the Persian Gulf based on the excavations of Sīrāf city. Indian Journal of Economics and Development 2, 6-13.

Piacentini, V. F., 1992, Merchants, Merchandise and Military Power in the Persian Gulf (Suriyanj/Shakriyaj-Siraf), in Atti della Accademia Nazionale dei Lincei, Memoire Series IX, Volume III, Fascicule 2, 110-189. Rome.

Rehatsek, E., 1882, Emporia, chiefly ports of Arab and Indian international commerce, before the Christian era, Journal of the Bombay Branch of the Royal Asiatic Society 15, 109-49.

Reinhardt, E. G., Goodman, B. N., Boyce, J. I., Lopez, G., van Hengstum, P., Rink, W. J., Mart, Y. and Raban, A., 2006, The tsunami of 13 December AD 115 and the destruction of Herod the Great's harbor at Caesarea Maritima, Israel. Geology 34.12, 1061-4.

Ricks, T. M., 1970, Persian Gulf Seafaring and East Africa: Ninth-Twelfth Centuries. African Historical Studies 3.2, $339-57$.

Sauvaget, J. (trans. \& ed.), 1948, Relation de la Chine et de l'Inde. Paris.

Sherrif, A., 2010, Dhow Cultures and the Indian Ocean: Cosmopolitanism, Commerce, and Islam, Columbia University Press.

Stein, A., 1937, Archaeological Reconnaissances in North-Western India and South-Eastern Iran. London.

Stiffe, A., 1895, Ancient Trading Centers of the Persian Gulf. I. Siráf. The Geographical Journal 6, $166-73$.

Tabari, 1987, The History of al-Tabari vol.1. State University of New York, Albany.

Tavakol, M. (trans.), 1958, Al-Baladuri, Futūh al-Buldan, 2, 545, Tehran.

UNESCO, nd, The historical Port of Siraf. http://whc.unesco.org/en/tentativelists/5195/ (accessed 10/29/2014)

Vincent, W., 1797, The Voyage of Nearchus from the Indus to the Euphrates, Collected from the Original Journal Preserved by Arrian. London: T. Cadell and W. Davies.

Vosmer, T., 1999, Indo-Arabian stone anchors in the western Indian Ocean and Arabian Sea. Arabian archaeology and epigraphy 10, 248-63.

Vosmer, T., Tripathi, S., Manikfan, A. and Mohamed, M., 2005, An Indo-Arabian type of stone anchor from Kannur, Kerala, west coast of India. IJNA 34.1, 131-7.

Whitehouse, D., 1968, Excavations at Sīrāf: First Interim Report. Iran 6, 1-22.

Whitehouse, D., 1969, Excavations at Sīrāf: Second Interim Report. Iran 7, 39-62. 
Whitehouse, D., 1970, Excavations at Sīrāf: Third Interim Report. Iran 8, 1-18.

Whitehouse, D., 1971, Excavations at Sīrāf: Fourth Interim Report. Iran 9, 1-17.

Whitehouse, D., 1972, Excavations at Sīrāf: Fifth Interim Report. Iran 10, 63-87.

Whitehouse, D. and Williamson, A., 1973, Sasanian Maritime Trade. Iran 11, 29-49.

Whitehouse, D., 1974, Excavations at Sīrāf: Sixth Interim Report. Iran 12, 1-30.

Whitehouse, D., 1980, Siraf III. The Congregational Mosque and other mosques from the ninth to the twelfth centuries. London.

Whitehouse, D., 2009, Siraf, History, Topography and Environment. Oxford.

Whitehouse, D. and Williamson, A., 1973, Maritime trade in the Gulf: the 11th and 12th centuries. World Archaeology 11, $29-49$.

Wilkinson, T. J., 1974, Agricultural decline in the Siraf region, Iran. Paléorient 2.1, 123-32.

Wilkinson, T. J. 2009, The Hinterland, in D. Whitehouse, Siraf, History, Topography and Environment, 54-76. Oxford.

Wilson, A., 1927, A Periplus of the Persian Gulf. The Geographical Journal March, 235-59.

Wilson, A., 1928, The Persian Gulf: an historical sketch from the earliest times to the beginning of the twentieth century. London.

Wulff, H., 1967, The Traditional Crafts of Persia. Their Development, Technology, and Influence on Eastern and Western Civilizations. Cambridge, MA.

Yajima Hikoichi, 1977, Maritime activities of the Arab Gulf people and the Indian Ocean world in the eleventh and twelfth centuries. Journal of Asian and African studies 14, 195-208.

Yāqūt, 1955-57, Mu’jam al-Buldan. Beirut. 